\title{
SAP-dependent and -independent regulation of innate T cell development involving SLAMF receptors
}

\author{
Jaime De Calisto ${ }^{1{ }^{*}}{ }^{\dagger}$, Ninghai Wang ${ }^{1 \dagger}$, Guoxing Wang ${ }^{1}$, Burcu Yigit ${ }^{1}$, Pablo Engel $^{2}$ and Cox Terhorst ${ }^{1}{ }^{*}$ \\ 1 Division of Immunology, Beth Israel Deaconess Medical Center, Harvard Medical School, Boston, MA, USA \\ ${ }^{2}$ Immunology Unit, Department of Cell Biology, Immunology and Neurosciences, Medical School, University of Barcelona, Barcelona, Spain
}

\section{Edited by:}

Hergen Spits, Academic Medical Center, Netherlands

\section{Reviewed by:}

Balbino Alarcon, Consejo Superior de Investigaciones Cientificas, Spain Koji Yasutomo, The University of Tokushima, Japan

\section{${ }^{*}$ Correspondence:}

Jaime De Calisto and Cox Terhorst Division of Immunology, Beth Israel Deaconess Medical Center, Harvard Medical School, 3 Blackfan Circle, Boston, MA 02115, USA

e-mail: jaimedecalisto@gmail.com; cterhors@bidmc.harvard.edu

t Jaime De Calisto and Ninghai Wang have contributed equally to this work.

Signaling lymphocytic activation molecule (SLAM)-associated protein (SAP) plays an essential role in the immune system mediating the function of several members of the SLAM family (SLAMF) of receptors, whose expression is essential forT, NK, and B-cell responses. Additionally, the expression of SAP in double-positive thymocytes is mandatory for natural killer T (NKT) cells and, in mouse, for innate $\mathrm{CD}^{+} \mathrm{T}$ cell development. To date, only two members of the SLAMF of receptors, Slamf1 and Slamf6, have been shown to positively cooperate during NKT cell differentiation in mouse. However, it is less clear whether other members of this family may also participate in the development of these innate $T$ cells. Here, we show that Slamf $[1+6]^{J^{-}}$and Slamf $[1+5+6]^{-/-}$B6 mice have $\sim 70 \%$ reduction of NKT cells compared to wild-type B6 mice. Unexpectedly, the proportion of innate CD8 ${ }^{+}$ T cells slightly increased in the Slamf $[1+5+6]^{-/-}$, but not in the Slamf $[1+6]^{-/-}$strain, suggesting that Slamf5 may function as a negative regulator of innate $\mathrm{CD} 8^{+} \mathrm{T}$ cell development. Accordingly, Slamf5 ${ }^{-/-}$B6 mice showed an exclusive expansion of innate $\mathrm{CD}^{+}$ T cells, but not NKT cells. Interestingly, the SAP-independent Slamf7-/- strain showed an expansion of both splenic innate $\mathrm{CD} 8^{+} \mathrm{T}$ cells and thymic NKT cells. On the other hand, and similar to what was recently shown in Slamf3-/- BALB/c mice, the proportions of thymic promyelocytic leukemia zinc finger (PLZF ${ }^{\text {hi }}$ ) NKT cells and innate $\mathrm{CD} 8^{+} \mathrm{T}$ cells significantly increased in the SAP-independent Slamf8-/- BALB/c strain. In summary, these results show that NKT and innate $\mathrm{CD}^{+} \mathrm{T}$ cell development can be regulated in a SAP-dependent and -independent fashion by SLAMF receptors, in which Slamf1, Slamf6, and Slamf8 affect development of NKT cells, and that Slamf5, Slamf7, and Slamf8 affect the development of innate $\mathrm{CD}^{+} \mathrm{T}$ cells.

\section{Keywords: SLAM, SAP, innate-like lymphocytes, NKT, innate $\mathrm{CD8}^{+} \mathrm{T}$ cells, $\mathrm{T}$ cell development, PLZF, Eomes}

\section{INTRODUCTION}

During mainstream $\mathrm{T}$ lymphocyte development, some of the key factors that drive the transition from double-positive (DP) $\mathrm{CD} 4^{+} \mathrm{CD}^{+}$precursors to single positive (SP) $\mathrm{T}$ cells involve antigen specificity and TCR strength (1-3). During this process, thymic epithelial cells interact with DP cells to determine the fate of immature thymocytes by orchestrating positive and negative selection (4-7). By contrast, homotypic DP-DP interactions drive development and selection of the so-called innate $\alpha \beta$ T lymphocytes, which include natural killer T (NKT) and innate $\mathrm{CD} 8^{+} \mathrm{T}$ cells (8-10). During development in the thymus, as well as in the effector phase in the periphery, NKT and innate $\mathrm{CD} 8^{+} \mathrm{T}$ cells, which have a restricted TCR repertoire, interact with different nonclassical MHC class I molecules (11-14). These cells are thought to be the first responder cells that can rapidly release various cytokines and control both viral and bacterial infections (15).

Signaling lymphocytic activation molecule (SLAM)-associated protein (SAP) (encoded by Sh2d1a in mouse) and several SLAM family (SLAMF) receptors provide DP thymocytes with positive signals that favor their maturation in the thymus (16-20). Cognate activation of NKT cells is restricted to CD1d-lipid complexes and is modulated by SAP and at least three members of the SLAMF of receptors (20-22). The homophilic interactions of Slamf1 and Slamf6 between DP thymocytes are particularly important for the development of the NKT cell lineage (20). Binding of SAP to the immunoreceptor tyrosine-based switch motifs (ITSMs) present in the cytoplasmic tail of several SLAMF receptors (23-25) promotes a unique interaction between the active configuration of the Src tyrosine kinase Fyn and the SLAMF receptor $(26,27)$, while at the same time blocking the recruitment of the protein phosphatases SHP-1 and SHP-2 (28-30), leading to efficient $\mathrm{T}$ cell activation and survival $(31,32)$. Recent evidence now demonstrates that Slamf3, another SAP-associated SLAMF receptor, acts as an inhibitory receptor for NKT and innate $\mathrm{CD} 8^{+} \mathrm{T}$ cell development (22). This suggests that differential SLAMF receptor expression can positively or negatively influence innate $\mathrm{T}$ cell development.

Non-conventional innate $\mathrm{CD} 8^{+} \mathrm{T}$ cells are also selected in the thymus from DP progenitors upon interaction with hematopoietic cells. Their TCR specificity is restricted to non-classical MHC class Ib molecules, including H2-M3 (histocompatibility 2, M region locus 3), Qa-1 (H2-T23), and MR1 (MHC class I related) (15). Like NKT cells, innate $\mathrm{CD}^{+}{ }^{+} \mathrm{T}$ cells bear an activated phenotype $\left(\mathrm{CD} 44^{\mathrm{hi}} \mathrm{CD} 122^{+}\right)$and promptly produce interferon-gamma 
(IFN- $\gamma$ ) upon activation. Moreover, positive selection of these innate $\mathrm{CD}^{+} \mathrm{T}$ cells in the thymus strictly depends on interleukin (IL)-15 (33-36). These lymphocytes have been most extensively described in $R l k^{-/-} I t k^{-/-}$(resting lymphocyte kinase/iterleukin2 -inducible $\mathrm{T}$ cell kinase) and $I t k^{-/-} \mathrm{B} 6$ mice, where these kinases are believed to set the threshold of TCR activation during lineage commitment. Hence, T cell clones with high MHC affinity will escape negative selection and acquire innate-like features (3, 15, 37-39). Notably, the expansion of these cells in $I t k^{-/-}$mice, and in other deficient B6 mouse strains with a similar phenotype $(10,40)$ depends on a subset of thymic promyelocytic leukemia zinc finger (PLZF' ${ }^{\text {hi }}$ ) NKT cells producing IL-4 (41-43). Importantly, this process also requires an intact SAP expression in the hematopoietic compartment (41). Sensing of IL-4 by developing innate $\mathrm{CD}^{+} \mathrm{T}$ cells upregulates one of the key transcription factors involved in the acquisition of the innate-like program by these cells, the T-box transcription factor, Eomesodermin (Eomes) (4246). In turn, Eomes directs the expression of granzyme B, perforin, IFN- $\gamma$ and, importantly, the expression of the IL-2/IL-15 receptor $\beta$ chain, CD122, which conveys responsiveness to the cytokine IL-15 (44).

Mutations in the human SH2D1A gene lead to X-linked lymphoproliferative syndrome (XLP) (28). This rare inherited disorder is characterized by exaggerated $\mathrm{T}$ - and $\mathrm{B}$-cell responses against Epstein-Barr virus (EBV), resulting in EBV-induced infectious mononucleosis, hypogammaglobulinemia, and a higher risk of developing various forms of lymphoma. Because patients with XLP lack NKT cells, the study of the regulation of their development and function by SLAMF receptors and SAP will shed light on the pathogenesis of this often-fatal disease. An important unanswered question in this field relates to how the coexpression of different arrays of SLAMF receptors favors the development of a particular innate $\mathrm{T}$ cell lineage. Therefore, in this study, we aimed to evaluate the relative contributions of three SAP-binding receptors, Slamf1, Slamf5, and Slamf6, and two SAP-independent receptors, Slamf7 and Slamf8, to the development of NKT and innate $\mathrm{CD} 8^{+} \mathrm{T}$ cells in the mouse.

\section{MATERIALS AND METHODS \\ MICE}

Slamf $[1+6]^{-/-}$and Slamf $[1+5+6]^{-/-}$mice on a C57BL/6 (B6) are described by Wang et al. (manuscript submitted for publication). J $\alpha 18^{-/-}$mice on a B6 background, originally from Dr. Taniguchi (Riken, Yokohama, Japan), were provided by Dr. Exley (Beth Israel Deaconess Medical Center (BIDMC), Harvard Medical School, Boston, MA, USA). Slamf7-/- B6 mice (B6N.129S5Slamf $7^{\text {tm1Lex}} /$ Mmucd, identification number 032574-UCD) were obtained from the Mutant Mouse Regional Resource Center (MMRRC), an NIH-funded strain repository, and was donated to the MMRRC by Genentech, Inc., Sh $2 d 1 a^{-/-}$mice on B6 and BALB/c backgrounds have been previously described (47). Slamf $8^{-/-}$mice on a BALB/c background have been previously described (48). Age- and sex-matched controls on the B6 and BALB/c backgrounds were purchased from The Jackson Laboratory (Bar Harbor, ME, USA) or from Charles River Laboratories (Wilmington, MA, USA). All animals were housed in the Center for Life Science animal facility of the BIDMC. The experiments were performed according to the guidelines of the Institutional Animal Care and Use Committee at BIDMC.

\section{GENERATION OF SLAMF5-/- MICE}

A B6 background murine bacterial artificial chromosome (BAC) clone (BAC RP23-77A8) was used as the PCR template for cloning the $5^{\prime}, 3^{\prime}$ arm and middle homologous fragments of the targeting vector. The PCR primers for the $6-\mathrm{kb} 5^{\prime}$ targeting arm were designed from the upstream sequence of exon 1 . The $2.1-\mathrm{kb}$ middle arm that contains the promoter region plus exon 1 , and the 4 -kb $3^{\prime}$ arm intron 1 fragments were generated by PCR. The PCR products were cloned into a targeting vector containing a LoxPFRT-Neo-FRT-LoxP cassette (Figure 2A). The resulting targeting construct was sequenced to confirm the correct sequences and orientation of the inserted PCR fragments. The targeting vector was then incorporated into Bruce 4 ES cells by electroporation. Southern blot hybridization was performed with a $5^{\prime}$ external probe to detect the homologous recombination event, and the positive clones were confirmed using a $3^{\prime}$ external probe. Four independent positive ES clones were microinjected into blastocysts from $\mathrm{BALB} / \mathrm{c}$ mice and gave rise to germline transmission of the Slamf5 mutant DNA. The resulting mice were bred with FLP transgenic B6 mice. FLP-mediated recombination resulted in the deletion of the FRT-flanked Neo gene. Subsequently, Neo-free mice were bred with CreTg mice to generate Slamf5 $5^{-/}$mice (Figures 2A,B).

\section{ANTIBODIES, TETRAMERS, AND FLOW CYTOMETRY}

PLZF (Mags.21F), Eomes (Dan11mag), TCR $\beta$ (H57-597), CD3 (17A2), and CD122 (TM-b1) antibodies were purchased from eBioscience (San Diego, CA, USA). CD4 (RM4.5), CD8 $\alpha$ (536.7), CD44 (IM7), IFN- $\gamma$ (XMG1.2), Slamf3 (CD229), and Slamf5 (CD84) antibodies were purchased from BioLegend (San Diego, CA, USA). Slamf1 (CD150), Slamf2 (CD48), Slamf4 (CD244), and Slamf6 (CD352) antibodies were purchased from BD Pharmingen (San Diego, CA, USA). PBS-57-loaded CD1d tetramers were provided by the National Institutes of Health tetramer facility (Atlanta, GA, USA). Briefly, 2-5 $\times 10^{6}$ thymocytes or splenocytes were incubated with the relevant cocktail of antibodies for $30 \mathrm{~min}$ on ice, washed twice with PBS $+5 \%$ FCS +5 mM EDTA, and acquired on a $\mathrm{BD}^{\mathrm{TM}}$ LSR II flow cytometer (BD Biosciences, San Jose, CA, USA). Dead cells were excluded by DAPI (Invitrogen, Carlsbad, CA, USA) or by using the Fixable Viability Dye eFluor ${ }^{\circledR}$ 455UV reagent (eBioscience). Data analysis was performed using FlowJo software (TreeStar, Ashland, OR, USA). For specific details concerning the FACS gating strategy used in this manuscript, refer Figures S1 and S2 in Supplementary Material. To accurately identify the background levels of CD122, CD44, Eomes, and PLZF from the true positive population, the fluorescence minus one (FMO) approach, in which all dyes except for the one of interest are added to the samples, was used in all the FACS analysis (49-51).

\section{INTRACELLULAR STAINING}

After surface staining (including the Fixable Viability Dye eFluor ${ }^{\circledR}$ 455UV), cells were fixed in IC/Fixation buffer (eBioscience) and then incubated for $30 \mathrm{~min}$ on ice with anti-PLZF plus anti-Eomes antibodies in $1 \times$ permeabilization buffer (eBioscience). After several washes, the cells were acquired on a $\mathrm{BD}^{\mathrm{TM}}$ LSR II flow cytometer (BD Biosciences). 
EX VIVO CELL ACTIVATION AND INTRACELLULAR CYTOKINE STAINING Total thymocytes from wild-type (WT) or Slamf8 $8^{-/}$BALB/c mice were incubated overnight at $37^{\circ} \mathrm{C}$ in the presence of the Cell Stimulation Cocktail (plus protein transport inhibitors) reagent (eBioscience). After surface staining (including the Fixable Viability Dye eFluor $\left.{ }^{\circledR} 455 \mathrm{UV}\right)$, cells were fixed/permeabilized and incubated for $30 \mathrm{~min}$ with anti-IFN- $\gamma$ antibody on ice. Samples were acquired on a BD ${ }^{\mathrm{TM}}$ LSR II flow cytometer. Data analysis was performed using FlowJo software.

\section{RNA ISOLATION AND REAL-TIME PCR (qPCR)}

Total RNA was isolated using TRIzol $^{\circledR}$ LS reagent (Invitrogen) and precipitated with isopropanol. All RNA samples were tested in duplicates, at $50 \mathrm{ng} /$ well, using the One-Step Real-Time RT-PCR Master Mix Reagent (Applied Biosystems ${ }^{\circledR}$, Part Number 4309169). qPCR was performed and analyzed on the 7500 FAST Real-Time PCR System (Applied Biosystems $\left.{ }^{\circledR}\right)$. Slamf8 (Mm01293286_m1), Eomes (Mm01351985_m1), Zbtb16 (Mm01176868_m1), Irf4 (Mm00516431_m1), IL-4 (Mm00445259_m1), and the Eukaryotic 18S ribosomal RNA Endogenous Control TaqMan ${ }^{\circledR}$ probes were purchased from Life Technologies (Carlsbad, CA, USA). The relative gene-specific fold change, normalized to $18 \mathrm{~S}$ rRNA, was calculated using the $2^{-\Delta \Delta \mathrm{ct}}$ method and expressed relative to WT levels $(\mathrm{WT}=1)$.

\section{STATISTICAL ANALYSIS}

Statistical significance was determined by unpaired $t$-test (twotailed with equal SD) using Prism software (GraphPad, San Diego, CA, USA). The $p$ value $<0.05$ was considered statistically significant.

\section{RESULTS}

\section{DIFFERENTIAL EXPRESSION OF SLAMF RECEPTORS BY MOUSE THYMOCYTE SUBSETS}

Since both NKT and innate $\mathrm{CD}^{+}{ }^{+} \mathrm{T}$ cells are selected from homotypic interactions between DP thymocytes, we thought that it was relevant to determine the specific SLAMF receptor expression pattern of these cells (Figure S1 in Supplementary Material). As previously reported $(20,22)$, we found that the homotypic SAPdependent receptors Slamf1, Slamf3, Slamf5, and Slamf6 are moderately to highly expressed by DP TCR $\beta^{\text {low }}$ thymocytes. Although Slamf2 is highly expressed by these cells, its receptor, Slamf4, is virtually absent, suggesting that this heterophilic interaction does not play a role during homotypic DP-DP contacts (Figure S1D in Supplementary Material). On the other hand, CD44 ${ }^{\text {hi }} \mathrm{NK} 1.1^{+}$ mature thymic NKT cells showed less Slamf1 and Slamf6 expression than their DP progenitors, while Slamf2, Slamf3, Slamf4, and Slamf5 were upregulated (Figure S1D in Supplementary Material). Thymic innate $\mathrm{CD}^{+} \mathrm{T}$ cells maintained the levels of Slamf1, Slamf4, and Slamf6 expression compared to DP TCR $\beta^{\text {low }}$ thymocytes, but slightly upregulated Slamf2, Slamf3, and Slamf5 (Figure S1D in Supplementary Material). Once in the spleen, mature NKT cells expressed Slamf1, Slamf5, and Slamf6 at a higher level than in the thymus, but lacked Slamf4 expression. Slamf2 and Slamf3 levels did not change on these cells. With the exception of Slamf1 and Slamf6, which were downregulated, the other SLAMF receptors showed a similar level of expression in splenic innate CD8 ${ }^{+}$
$\mathrm{T}$ cells compared to their thymic counterparts (Figure S1D in Supplementary Material). Together, these data suggest that the SAP-dependent receptors Slamf1, Slamf3, Slamf5, and Slamf6 may participate in early homotypic cell-cell interactions leading to NKT and/or innate $\mathrm{CD} 8^{+} \mathrm{T}$ cell differentiation.

\section{SAP-INDEPENDENT RECEPTORS SLAMF7 AND SLAMF8 ARE HIGHLY EXPRESSED IN THYMIC-RESIDENT DENDRITIC CELLS}

We used the Gene Skyline tool from the Immunological Genome Project's website [Immgen.org; (52)] to determine Slamf7, Slamf8, and Slamf9 mRNA expression levels by different thymic populations (Table 1). Slamf7 mRNA was differentially expressed by mature NKT cells, dendritic cells (DC), and medullary epithelial cells, while Slamf8 mRNA was only present in DC and thymic fibroblasts, but not in DP thymocytes. Slamf 9 mRNA was moderately expressed by DP thymocytes, DC, and medullary epithelial cells only. Furthermore, Sh2dla mRNA (encoding SAP) was only detected in DP and mature NKT cells, while Sh2d1b1 mRNA (encoding EAT-2A) was not expressed by any of the cell subsets analyzed. These data suggest that the SAP-independent SLAMF receptors, Slamf8 and Slamf9, may also modulate innate $\mathrm{T}$ cell differentiation in mice.

\section{SLAMF1 AND SLAMF6 CONTROL NKT BUT NOT INNATE CD8+ T CELL DEVELOPMENT}

Although disruption of Slamf1 or Slamf6 gene only marginally affects NKT cell development (20) (Table 2), the use of mixed-bone marrow chimeras or a lentivirus-based knockdown approach have suggested that these SLAMF receptors positively cooperate during NKT cell differentiation $(20,53)$. Therefore, to better understand the consequences of a combined deficiency of more than one SLAMF receptor during innate $\mathrm{T}$ cell development, we generated Slamf $[1+6]^{-/-}$and Slamf $[1+5+6]^{-/-}$B6 mice by two sequential homologous recombination-based gene disruptions (Wang et al., manuscript submitted for publication).

Both Slamf $[1+6]^{-/-}$and Slamf $[1+5+6]^{-/-}$B6 mice developed normally and had no gross phenotype as compared to their WT littermates (Wang et al., manuscript submitted for publication). Consistent with the outcomes of our previous bone

Table 1 | mRNA levels in SAP-independent SLAMF receptors and SLAMF adaptors expressed by different murine thymic populations.

\begin{tabular}{|c|c|c|c|c|c|}
\hline Cell subset & Slamf7 & Slamf8 & Slamf9 & Sh2d1a & Sh2d1b1 \\
\hline DP thymocytes & - & - & + & + & - \\
\hline Mature NKT & ++ & - & - & + & - \\
\hline $\mathrm{CD}^{-} \mathrm{DC}$ & +++ & ++ & + & - & - \\
\hline $\mathrm{CD}^{+} \mathrm{DC}$ & +++ & ++ & + & - & - \\
\hline Medullary epithelial cells & + & - & + & - & - \\
\hline Thymic fibroblasts & - & + & - & - & - \\
\hline
\end{tabular}

DP thymocyte: $C D 4^{+} C D 8^{+} T C R \beta^{-1 / 0 w} C D 69$; mature NKT: TCR $\beta^{+} P B S-57-C D 1 d-$ $\mathrm{Tet}^{+} \mathrm{CD} 44^{+} \mathrm{NK} 1.1^{+}$; DC: $\mathrm{CD} 11 \mathrm{C}^{+} \mathrm{MHC}-1 \mathrm{I}^{+} \mathrm{CD} 11 \mathrm{~b}^{-} \mathrm{CD} 4^{-}$; medullary epithelial cells: CD45- EpCAM+ Ly51- MHC-I/li ; thymic fibroblast: CD45- PDGFR $\alpha^{+} \mathrm{MTS15}^{+}$. Symbols represent the relative normalized mRNA levels (arbitrary units) according to the following criteria: (-), <50; (+), 50-500; (++), 500-1000; $(+++),>1000$. 
Table 2 | Effects of SAP and SLAMF receptor deficiencies on innate T cell development in the thymus of B6 mice.

\begin{tabular}{|c|c|c|c|c|c|c|c|c|}
\hline C57BL/6 & Sh2d1a $a^{-/-}$ & $F 1^{-/-}$ & $F 5^{-/-}$ & $F 6^{-/-}$ & $F[1+6]^{/-}$ & $F[1+5+6]^{-/-}$ & $\mathrm{F3}^{-/-}$ & $F 7^{-1-}$ \\
\hline Mature NKT & $\downarrow \downarrow \downarrow$ & $\downarrow$ & \pm & $\downarrow$ & $\downarrow \downarrow$ & $\downarrow \downarrow$ & $\uparrow$ & $\uparrow$ \\
\hline Innate CD8 & $\uparrow$ & $?$ & \pm & $?$ & \pm & \pm & $=$ & $=$ \\
\hline
\end{tabular}

$\downarrow$, Reduction; $\uparrow$, expansion; \pm , marginal/some effect; $=$, no effect; ?, no data available.

marrow chimera experiments (20), NKT cell development was severely impaired as judged by a $70 \%$ reduced frequency and absolute cell counts (data not shown) of PBS-57 CD1d-tetramer (CD1d-Tet) reactive cells (NKT) both in the thymus and spleen of Slamf $[1+6]^{-/-}$and Slamf $[1+5+6]^{-/-}$B6 mice (Figures 1A,B). Importantly, these results further confirm the significance of Slamfl and Slamf6 coexpression in DP thymic precursors for NKT cell development. Since the additional disruption of the Slamf5 gene in the triple-knockout strain did not further reduce the NKT cell compartment (Figures 1A,B), we conclude that in the absence of Slamf1 and Slamf6, Slamf5 does not play a major role in NKT cell differentiation.

As NKT cells have been shown to support innate $\mathrm{CD}^{+} \mathrm{T}$ cell development $(10,43)$, we hypothesized that both Slamf $[1+6]^{-1-}$ and Slamf $[1+5+6]^{-/-}$B6 mice would present a marked reduction in the proportions of innate $\mathrm{CD}^{+} \mathrm{T}$ cells due to the dramatic loss of NKT cells (Figures 1A,B). Unexpectedly, we did not find a significant impairment of the innate $\mathrm{CD} 8^{+} \mathrm{T}$ cell pool $\left(\mathrm{CD} 44^{\mathrm{hi}} \mathrm{CD} 122^{+}\right)$in the thymus of Slamf $[1+6]^{-/-}$or Slamf $[1+5+6]^{-1-}$ B6 mice (Figures 1C,D). Instead, we found a slight increase of splenic innate-like $\mathrm{CD} 8^{+} \mathrm{T}$ cells in the absence of Slamf1, Slamf5, and Slamf6 (Figures 1C,D). These results raised the possibility that Slamf5 could be acting as a SAPdependent negative regulator of innate $\mathrm{CD}^{+} \mathrm{T}$ cell expansion in the periphery.

The above findings also suggest that the requirement of NKT cells during innate $\mathrm{CD} 8^{+} \mathrm{T}$ cell development and/or expansion is not absolute. To test this, we looked for the presence of innate-

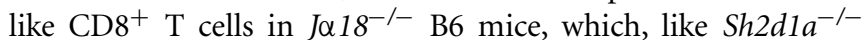
B6 mice, completely lack NKT cells (59). Similar to what we found in Slamf $[1+5+6]^{-/-}$mice (Figures 1C,D), Ja $18^{-/-}$B6 mice did not present significant alterations in the innate $\mathrm{CD} 8^{+}$ $\mathrm{T}$ cell compartment, showing similar percentages of these cells both in the thymus and spleen compared to WT (Figures 1E,F). Intriguingly, although SAP was shown to be required for the selection of innate-like $\mathrm{CD} 8^{+} \mathrm{T}$ cells in the $I t k^{-/-}$background (40), we found a significant increase of these cells in the thymus of Sh2d1 $a^{-/-}$B6 mice (Figures 1E,F). Together, these results show that in the absence of NKT cells, innate-like $\mathrm{CD}^{+} \mathrm{T}$ cells can develop relatively normally in the thymus and spleen of B6 mice.

\section{SLAMF5 IS A NEGATIVE REGULATOR OF INNATE CD8 ${ }^{+}$T CELL EXPANSION}

The enlarged population of $\mathrm{CD} 44^{\mathrm{hi}} \mathrm{CD} 122^{+} \mathrm{CD} 8^{+} \mathrm{T}$ cells found in the spleen of Slamf $[1+5+6]^{-/-}$mice but not in the spleen of Slamf $[1+6]^{-/-}$mice (Figures 1C,D) prompts us to assess whether the Slamf5/SAP axis could be negatively regulating the development of these non-conventional lymphocytes. Therefore, we used the single-knockout Slamf5 $5^{-/}$mouse to check this hypothesis (Figures 2A,B). Indeed, we found a significant increase in the percentage and absolute counts (data not shown) of innatelike $\mathrm{CD}^{+} \mathrm{T}$ cells in the spleen of Slamf $5^{-/-}$mice compared to WT B6 mice. In the thymus, we observed a similar trend, but this result did not reach statistical significance (Figures 2C,D). However, the NKT cell compartment of Slamf5 $5^{-1}$ mice appeared slightly reduced by the absence of this receptor (Figures 2E,F). Together, these data suggest that the SAP-binding receptor Slamf5 may be acting as a negative regulator of innate $\mathrm{CD} 8^{+} \mathrm{T}$ cell development and/or expansion in B6 mice (Table 2).

\section{SAP-INDEPENDENT RECEPTOR SLAMF7 NEGATIVELY CONTROLS THE DEVELOPMENT OF INNATE LYMPHOCYTES IN B6 MICE}

Next, we evaluated whether Slamf7 deficiency (Figures 3A,B) could also alter the innate $\mathrm{CD}^{+}$and/or NKT cell compartment of $\mathrm{B} 6$ mice. We found a significant expansion of CD44 ${ }^{\mathrm{hi}} \mathrm{CD} 122^{+}$ innate-like $\mathrm{CD} 8^{+} \mathrm{T}$ cells in the spleen but not in the thymus of Slamf $7^{-1-}$ mice as compared to WT B6 controls (Figures 3C,D). In contrast, and as shown in Figures 1E,F, Sh2d1 ${ }^{-/-}$B6 mice displayed a clear expansion of $\mathrm{CD} 44^{\mathrm{hi}} \mathrm{CD} 122^{+}$innate-like $\mathrm{CD} 8^{+}$ $\mathrm{T}$ cells in the thymus (Figures 3C,D). We also observed a significant increase of CD44hi mature NKT cells in the thymus of Slamf $7^{-1-}$ mice (Figures 3E,F). As expected, Sh2d1 $1 a^{-1-}$ B6 mice almost completely lack mature NKT cells (Figures 3E,F). These results suggest that endogenous expression of Slamf7 negatively influences the fate of both innate $\mathrm{CD} 8^{+}$and NKT cells. Whether this occurs via EAT-2A, a second adaptor that was shown to bind the Slamf7 receptor $(23,24)$ or via SAP recruitment to the cytoplasmic tail of Slamf7 remains to be determined.

\section{EXPANSION OF INNATE-LIKE T CELLS IN SLAMF8-/- BALB/c MICE}

To date, nothing is currently known about the contribution of the SAP-independent receptor Slamf8 during T cell development. Thus, in order to test whether the lack of Slamf8 may influence this process, we systematically identified specific $\mathrm{T}$ cell subsets present in the thymus and spleen of Slamf8 ${ }^{-/}$BALB/c mice by FACS (Figure 4E; Figure S2A in Supplementary Material). We also included SAP-deficient BALB/c mice (Sh2d1 $\left.a^{-/-} \mathrm{BALB} / \mathrm{c}\right)$ in these studies in order to evaluate the role of this SLAMF adaptor in a murine background other than B6. We readily identified an expansion of TCR $\beta^{\text {hi }}$ CD8SP T cells in the thymus of Slamf $8^{-/-}$ mice compared to WT BALB/c mice. This alteration appeared to be specific for this organ, as this was not observed in the spleen of Slamf $8^{-/-}$mice (expressed as a CD8:CD4 ratio; Figures 4A,B), a phenotype resembling Slamf $3^{-/-}$mice on the same background (22) (Table 3). 

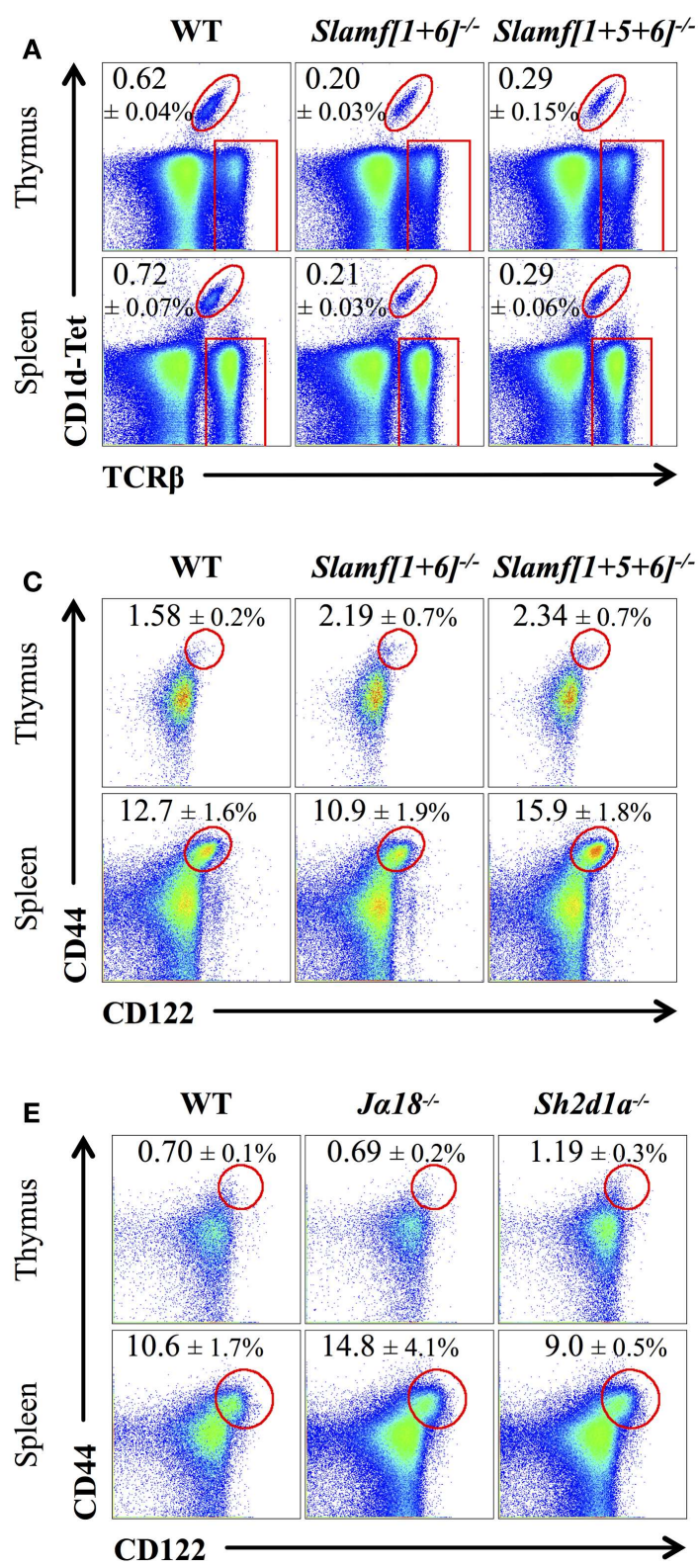

FIGURE 1 | Slamf1 and Slamf6 are required for NKT cell but not for innate CD8 $^{+} \mathbf{T}$ cell development. (A) Representative FACS plots showing PBS-57 CD1d-tetramer (CD1d-Tet) reactive NKT cells from thymus or spleen of WT, Slamf $[1+6]^{--}$or Slamf $\left[1+5+65^{-1}\right.$ B 6 mice. FACS plots are gated on live singlets lymphocytes. (B) Percentage of CD1d-Tet ${ }^{+} T C R \beta^{\text {inter }}$ cells in thymus (left) or spleen (right) of WT, Slamf $[1+6]^{-/}$or

Slamf $[1+5+6]^{-/}$B6 mice. (C) Representative FACS plots showing the expression of CD44 and CD122 on single positive CD8T cells (CD8SP) from thymus or spleen of WT, Slamf $[1+6]^{--}$or Slamf $[1+5+6]^{--}$B6 mice. FACS plots are gated on live singlets lymphocytes TCR $\beta^{\text {hi }}$ CD8SP (thymus) or TCR $\beta^{+}$CD8SP (spleen). (D) Percentage of CD44 hi CD122+ CD8SPT cells in thymus (left) or spleen (right) of WT, Slamf $\left[1+6 J^{--}\right.$or

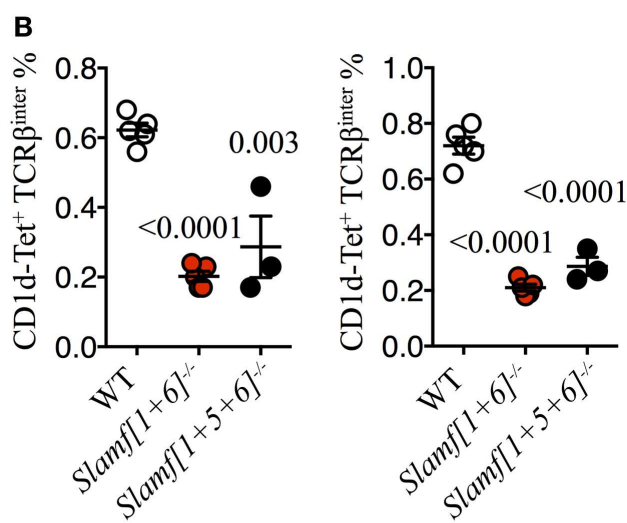

D
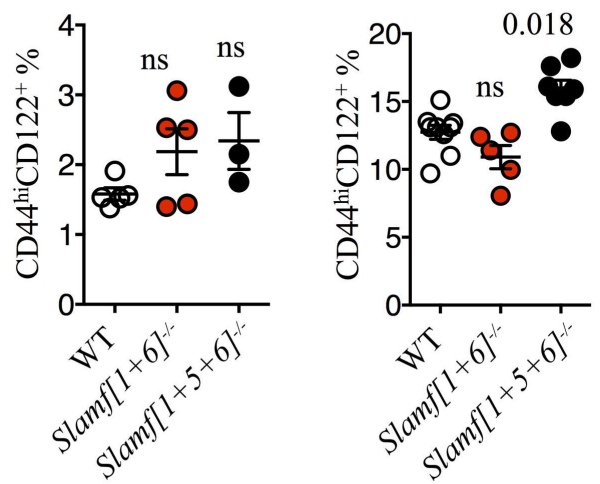

$\mathbf{F}$
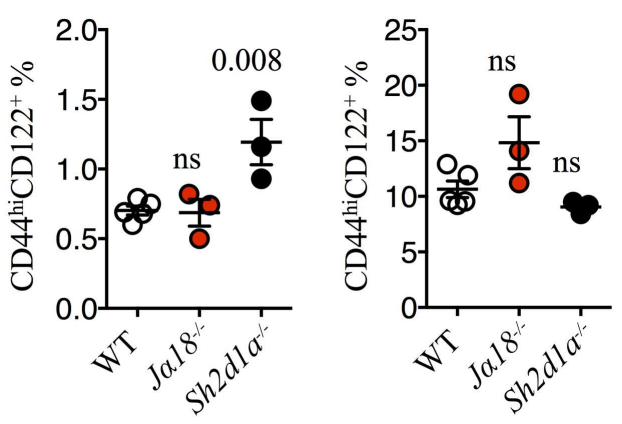

Because of the CD8-biased $\mathrm{T}$ cell expansion observed in Slamf $8^{-/-}$BALB/c mice, we analyzed the intracellular expression of the CD8-specific T-box transcription factor Eomes. Consistent with the above results, we found a twofold increase
Slamf $[1+5+6]^{-1}$ B6 mice. (E) Representative FACS plots showing the expression of CD44 and CD122 on CD8SPT cells from thymus or spleen of WT, Ja $18^{-/}$or Sh2d1 $a^{-/}$B6 mice. FACS plots are gated on live singlets lymphocytes TCR $\beta^{\text {hi }}$ CD8SP (thymus) or TCR $\beta^{+}$CD8SP (spleen).

(F) Percentage of CD44 hi CD122+ CD8SPT cells in thymus (left) or spleen

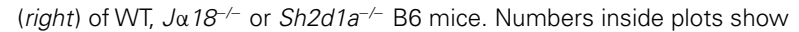
the mean percentage \pm SD of NKT cells (A), or innate-like CD8 $8^{+} T$ cells (C, E). Red rectangles in (A) depict the lymphocyte gate in which innate $\mathrm{CD}^{+} \mathrm{T}$ cells were analyzed. Cumulative graphs show the results of two independent experiments, mean \pm SEM. The $p$ values were calculated by unpaired $t$-test between the WT group and the knockout group. A value of $p<0.05$ was considered significant; ns, non-significant. in the proportion of Eomes ${ }^{+}$CD8SP $\mathrm{T}$ cells in the thymus of Slamf $8^{-1-}$ mice (Figures 4C,D). Interestingly, and despite the comparable ratio of $\mathrm{CD} 8: \mathrm{CD} 4 \mathrm{~T}$ cells found in the spleen of Slamf8 $8^{-1}$ mice, Eomes ${ }^{+}$CD8SP $\mathrm{T}$ cells also increased in 

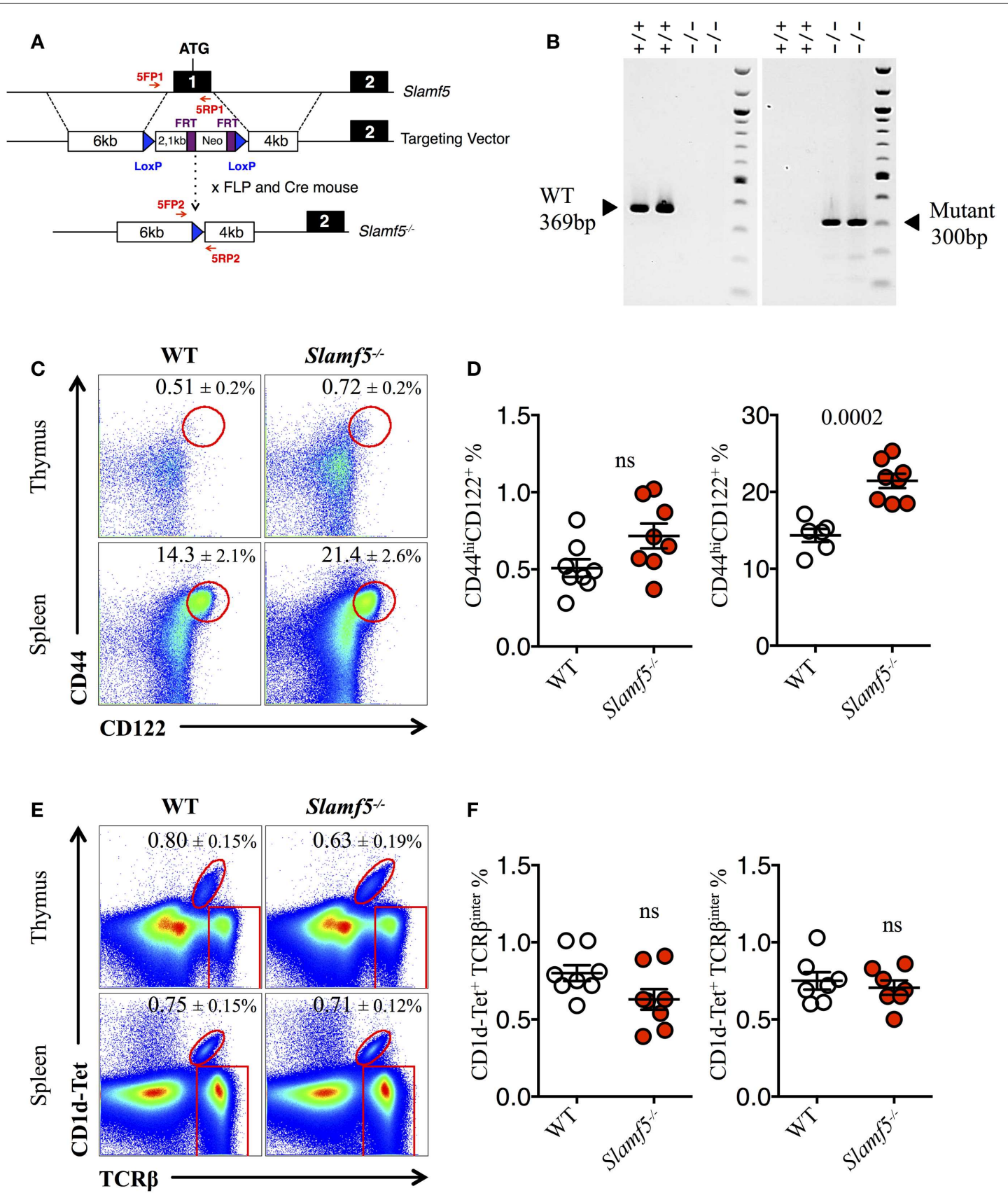

$\mathbf{F}$
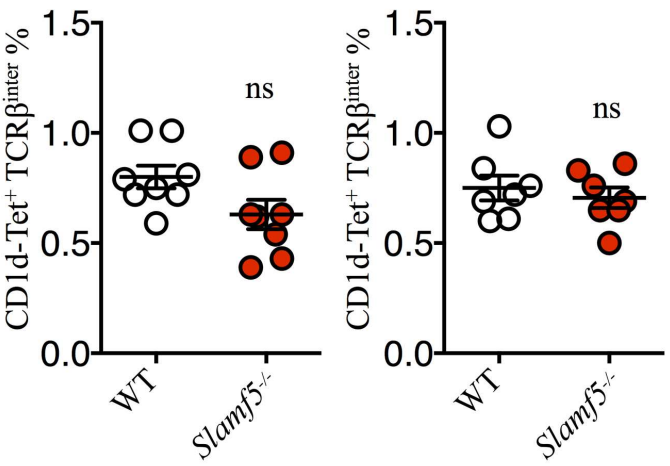

FIGURE 2 | Slamf5 acts as a negative modulator of innate $\mathrm{CD8}^{+} \mathrm{T}$ cell. (A) Schematic representation of the Slamf5 conditional targeting strategy. Homologous recombination of the targeting construct with the Slamf5 genomic locus results in the introduction of an FRT-Neo-FRT cassette along with two LoxP sites surrounding exon 1. Subsequent FLP- and Cre-mediated recombination events lead to the generation of the Slamf5 $5^{-1}$ gene.

(B) Mouse tail DNA was isolated and screened by PCR using the two sets of primers (5FP1 + 5RP1 and 5FP2 + 5RP2) depicted in (A). Fragments of $~ 369$ and $\sim 300$ base pairs are expected for the WT and mutant alleles, respectively. The PCR gel shows a representative result of two WT and two Slamf5 mouse DNA samples. (C) Representative FACS plots showing the expression of CD44 and CD122 on CD8SPT cells from thymus (TCR $\beta^{\text {hi }}$ ) or spleen (TCR $\beta^{+}$) of WT or Slamf5 $5^{--}$B6 mice. FACS plots are gated on live singlets lymphocytes TCR $\beta^{\text {hi }}$ CD8SP (thymus) or TCR $\beta^{+}$CD8SP (spleen). (D) Percentage of CD44hi $\mathrm{CD} 122^{+} \mathrm{CD} 8 \mathrm{SPT}$ cells in thymus (left) or spleen (right) of WT or Slamf5 $5^{--}$B6 mice. (E) Representative FACS plots showing PBS-57 CD1d-tetramer (CD1d-Tet) reactive NKT cells from thymus or spleen of WT or Slamf5 $5^{--}$B6 mice. FACS plots are gated on live singlets lymphocytes. (F) Percentage of CD1d-Tet ${ }^{+} T C R \beta^{\text {inter }}$ cells in thymus (left) or spleen (right) of WT or Slamf5 ${ }^{-1}$ mice. Numbers inside plots show the mean percentage $\pm S D$ of innate-like CD8 ${ }^{+}$T cells (C), or NKT cells (E). Red rectangles in (E) depict the lymphocyte gate in which innate $\mathrm{CD} 8^{+} \mathrm{T}$ cells were analyzed. Cumulative graphs show the results of three independent experiments, mean \pm SEM. The $p$ values were calculated by unpaired $t$-test between the WT group and the Slamf5 $5^{-/}$group. A value of $p<0.05$ was considered significant; ns, non-significant. 


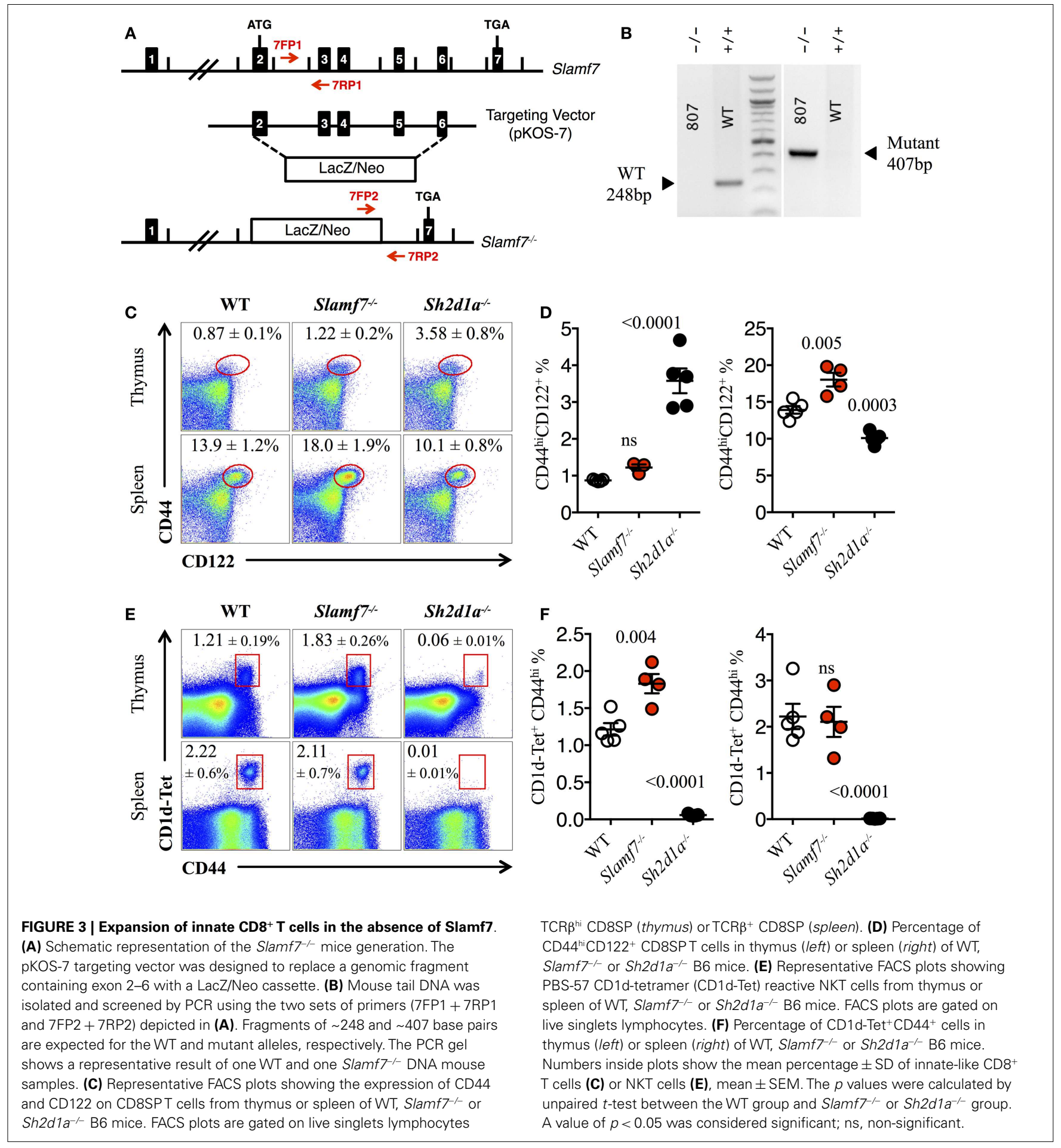

this organ compared to WT mice (Figures 4C,D). In contrast, Sh2d1a ${ }^{-/-}$mice, which displayed no change in CD8:CD4 ratios in thymus or spleen, showed a dramatic decrease in Eomes ${ }^{+}$ $\mathrm{CD}^{+} \mathrm{T}$ cells (Figures $4 \mathrm{C}, \mathrm{D}$ ). On the other hand, the relative expression of Eomes and Irf4 (IFN regulatory factor 4) mRNA, whose expression was shown to inversely correlate with that of Eomes in recently activated $\mathrm{CD}^{+} \mathrm{T}$ cells $(3,60)$, did not differ between Slamf $8^{-/-}$and WT resting thymocytes (Figure 4F). In conclusion, the absence of Slamf8 expression favors the expansion of a CD8SP $\mathrm{T}$ cell population expressing Eomes in thymus and spleen. Moreover, although the absence of SAP expression does not alter the CD8:CD4 ratios in thymus or spleen, it dramatically decreases the frequency of Eomes ${ }^{+}$CD8SP T cells in these organs. 

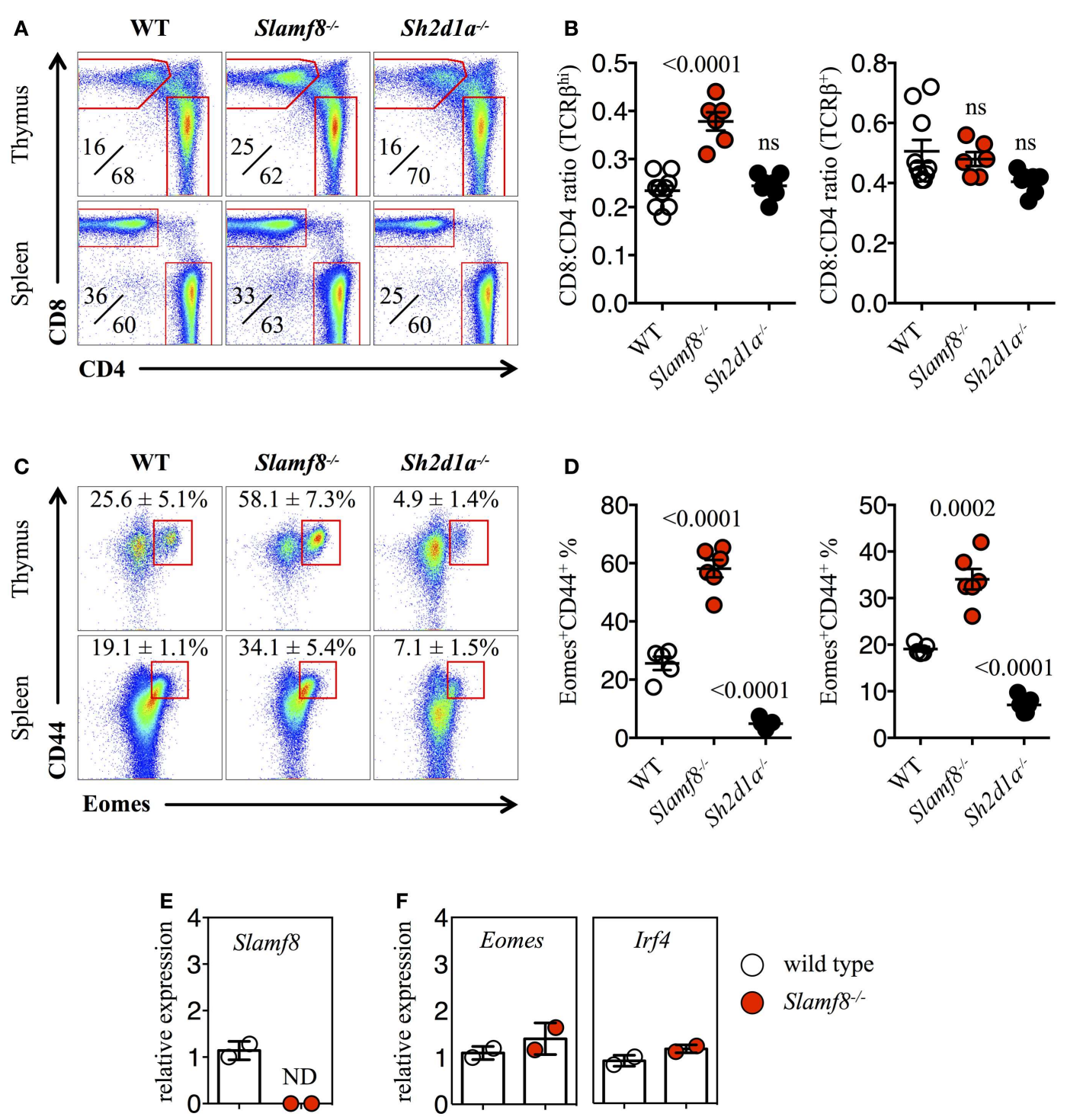

wild type

FIGURE 4 | Lack of Slamf8 expression triggers an expansion of Eomes ${ }^{+}$ CD8 $^{+} \mathbf{T}$ cells. (A) Representative FACS plots showing CD4 and CD8 single positive (SP) T cells from thymus or spleen of WT, Slamf8-- or Sh2d1 $a^{-1-}$ BALB/c mice. FACS plots are gated on live singlets TCR $\beta^{\text {hi }}$ (thymus) or TCR $\beta^{+}$ (spleen) lymphocytes. (B) CD8:CD4 ratio of TCR $\beta^{\text {hi }}$ thymocytes (left) or TCR $\beta^{+}$ splenocytes (right) from WT, Slamf8 ${ }^{-1}$ or Sh2d1 $a^{-/-}$BALB/c mice.

(C) Intracellular staining for the transcription factor Eomesodermin (Eomes) in thymus or spleen of WT, Slamf8 ${ }^{--}$or Sh2d1 $a^{-/}$BALB/c mice. FACS plots are gated on live singlets lymphocytes TCR $\beta^{\text {hi }}$ CD8SP (thymus) or TCR $\beta^{+}$CD8SP (spleen). (D) Percentage of Eomes ${ }^{+} \mathrm{CD} 44^{+}$CD8SPT cells in thymus (left) or spleen (right) of WT, Slamf8 ${ }^{--}$or Sh2d1a $a^{-/}$BALB/c mice. (E) The relative mRNA expression of Slamf8, or Eomes and Irf4 (F) was determined in total thymocytes from WT or Slamf8- ${ }^{--}$BALB/c mice by real-time PCR. Results were normalized to the expression of the housekeeping gene 18S rRNA and expressed relative to WT BALB/c levels $(W T=1)$; ND, not detected. Numbers inside plots show the mean percentage $(\mathbf{A})$ or the mean percentage $\pm S D$ (C) of the indicated population. Cumulative graphs show the results of four independent experiments, mean \pm SEM. The $p$ values were calculated by

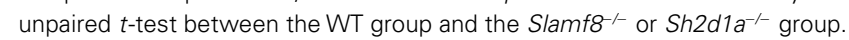
A value of $p<0.05$ was considered significant; ns, non-significant.

\section{CD44 ${ }^{\text {hi }}$ CD122+ CD8SP T CELLS IN SLAMF8-/- MICE EXPRESS THE TRANSCRIPTION FACTOR EOMES AND RAPIDLY PRODUCE IFN- $\gamma$ UPON STIMULATION}

Consistent with the enlarged Eomes ${ }^{+} \mathrm{CD}^{+}$T cell compartment in Slamf $8^{-/-}$mice, we found a larger proportion of CD $44^{\text {hi }} \mathrm{CD} 122^{+}$ innate-like $\mathrm{CD}^{+} \mathrm{T}$ cells in these mice (Figures 5A,B), whereas Sh $2 d 1 a^{-/-}$mice showed a significant reduction of these cells in the thymus and spleen (Figures 5A,B). Interestingly, within the thymic innate-like CD8 ${ }^{+} \mathrm{T}$ cell population, Slamf $8^{-/-}$mice showed a higher proportion of Eomes ${ }^{+}$cells compared to WT mice (Figures 5C,D), supporting the idea that the expanded $\mathrm{CD}^{+} \mathrm{T}$ cell population documented in Figure 4 corresponds to truly bona fide innate $\mathrm{CD} 8^{+} \mathrm{T}$ cells. Consistent with a reduced CD $44{ }^{\text {hi }}{ }^{2} 122^{+}$CD8SP $\mathrm{T}$ cell population, Sh2d1a ${ }^{-/-}$BALB/c mice displayed a dramatic reduction in Eomes ${ }^{+}$CD8SP $\mathrm{T}$ cells in the thymus and, to a lesser extent, in the spleen as well 
Table 3 | Effects of SAP and SLAMF receptor deficiencies on innate T cell development in the thymus of BALB/c mice.

\begin{tabular}{lcccc}
\hline BALB/c & $\boldsymbol{S h} \boldsymbol{d} \boldsymbol{d 1 a ^ { - / }}$ & $\boldsymbol{F 1}^{-/-}$ & $\boldsymbol{F 3}^{-/-}$ & $\boldsymbol{F 8}^{-/-}$ \\
\hline Mature NKT & $\downarrow \downarrow \downarrow$ & $=$ & $\uparrow \uparrow \uparrow$ & \pm \\
Innate CD8 & $\downarrow \downarrow \downarrow$ & $\downarrow \downarrow$ & $\uparrow \uparrow \uparrow$ & $\uparrow \uparrow \uparrow$ \\
References & This work & Unpublished observations & (22) & This work
\end{tabular}

$\downarrow$, Reduction; $\uparrow$, expansion; \pm , marginal/some effect; $=$, no effect

(Figures 5C,D). These seemingly contrasting results, compared to Sh $2 d 1 a^{-1-}$ B6 mice (Figures 1 and 3; Table 2), indicate that the consequences of a SAP mutation will be greatly influenced by the mouse background. In fact, this phenomenon was previously observed in Slamf3 $3^{-/-}$mice in which profound alterations of the innate $\mathrm{CD}^{+} \mathrm{T}$ cell compartment were only present on the BALB/c but not on the B6 background $(22,58)$ (Table 3 ).

Finally, to confirm that the expanded population of innate-like $\mathrm{CD}^{+} \mathrm{T}$ cells found in Slamf8 ${ }^{-/-}$mice had the ability to produce effector cytokines upon activation, we stimulated total thymocytes ex vivo with PMA plus ionomycin. This treatment resulted in a higher percentage of IFN- $\gamma$ producing Slamf $8^{-/-}$CD8SP T cells compared to WT cells (Figures 5E,F). Together, these data demonstrate that the lack of Slamf8 expression results in a preferential expansion of $\mathrm{CD}^{+} \mathrm{T}$ cells with an innate-like phenotype. These cells express the transcription factor Eomes and produce IFN- $\gamma$ upon stimulation, suggesting that SAP-independent signals can also modulate the generation of non-conventional $\mathrm{CD} 8^{+} \mathrm{T}$ cells in mice.

\section{SLAMF8-/- MICE HAVE AN ENLARGED PROPORTION OF NKT PLZF ${ }^{\mathrm{hi}}$ CELLS IN THE THYMUS}

Recent studies have strongly suggested that thymic NKT cells can change the size of the innate $\mathrm{CD}^{+} \mathrm{T}$ cell pool via the production of IL-4 (10, 22, 42, 43, 61). Therefore, we evaluated whether we could find an expansion of NKT cells in the thymus and spleen of Slamf $8^{-1-}$ mice. Unlike Slamf $3^{-1-}$ BALB/c mice, in which an expansion of NKT cells was reported (22), we did not observe significant differences in the percentage of total NKT cells in the thymus or spleen of Slamf $8^{-/-}$mice compared to WT mice (Figures 6A,B). Accordingly, and consistent with an essential role of SAP during NKT cell development on B6 mice (17-19), Sh2d1a $a^{-/-}$BALB/c mice were almost completely devoid of these cells (Figures 6A,B). These observations unmistakably demonstrate that SAP-derived signals contribute enormously to the NKT cell lineage commitment independently of the mouse genetic background. Moreover, the lack of Slamf8 does not greatly affect the proportions of CD1d-Tet reactive NKT cells.

Just as Eomes controls the effector program of innate $\mathrm{CD} 8^{+}$ T cells (44), NKT cells in the thymus rely on the expression of PLZF to gain their phenotypical and functional properties (6265). Although we did not observe significant differences in the percentage of CD $44^{\text {hi }}$ NKT cells between WT and Slamf $8^{-/-}$mice (Figures 6A,B), the proportion of PLZF ${ }^{\text {hi }} \mathrm{CD} 1 \mathrm{~d}$-Tet reactive cells was slightly higher both in the thymus and spleen of Slamf $8^{-/-}$ mice, as judged by intracellular PLZF staining (Figures 6C,D). In contrast, we found a significant reduction of the PLZF ${ }^{\text {hi }}$ population in the few NKT cells that we could detect in Sh2d1a $a^{-/-}$ BALB/c mice (Figures 6C,D). However, we did not detect differences in $Z b t b 16$ mRNA expression (encoding PLZF) between WT and Slamf $8^{-/-}$resting thymocytes. On the other hand, an approximately threefold increase in $I L-4$ mRNA (encoding IL-4) was detected in Slamf $8^{-1-}$ samples (Figure 6E). Together, these data show that the absence of Slamf8 expression licenses the expansion of both Eomes ${ }^{+}$CD8SP and PLZF ${ }^{\text {hi }}$ NKT cells preferentially in the thymus, and that those NKT cells are biased to produce IL-4, which in turn may contribute to the expansion of innate $\mathrm{CD} 8^{+} \mathrm{T}$ cells in Slamf $8^{-/-}$mice. This proposes an unprecedented role for the SAP-independent SLAMF receptor Slamf8 in regulating innate T cell development.

\section{DISCUSSION}

Inadequate TCR-related signaling during $\mathrm{T}$ cell development, including overly strong or weak MHC/TCR interactions, results in the deletion of up to $90 \%$ of developing thymocytes (66). SLAMF receptors and the adaptor SAP have been shown to play an essential modulatory role during selection of non-conventional $\mathrm{T}$ cells, including NKT and innate $\mathrm{CD}^{+} \mathrm{T}$ cells. These homophilic interactions provide developing NKT cells, and likely innate $\mathrm{CD} 8^{+} \mathrm{T}$ cells, with both positive and negative developmental cues. Interestingly, the SLAMF/SAP pathway does not seem to affect conventional $\alpha \beta \mathrm{T}$ cell development, suggesting the existence of a specialized mechanism by which innate lymphocytes are preferentially generated in the thymus. These observations could be partially explained by the particular modus operandi of the SLAMF receptors, in which, as self-ligands, homotypic cell-cell contacts can be specially favored by homophilic SLAMF-SLAMF interactions. Additionally, as the expression of SLAMF receptors is confined to the hematopoietic compartment, interactions of SLAMF-expressing DP thymocytes with thymic epithelial cells cannot lead to a productive activation of the SLAMF/SAP signaling cascade in those cells. On the other hand, if two interacting DP thymocytes display a similar SLAMF receptor expression pattern, then their homophilic SLAMF-SLAMF interactions will be particularly favored, leading to a successful expansion of these clones.

The generation of double and triple SLAMF-deficient mouse strains allowed us for the first time to study the simultaneous effects of a total abolition of Slamf1, Slamf5, and Slamf6 on NKT and innate $\mathrm{CD} 8^{+} \mathrm{T}$ cell development. Unlike our previous experiments using mixed-bone marrow chimeras (20), these mice provided us with the unique opportunity to avoid any possible unwanted effects derived from the sterile inflammation induced by the gamma radiation and/or the possible contribution of radioresistant cells inherent in these kinds of experiments. Since both Slamf $[1+6]^{-/-}$and Slamf $[1+5+6]^{-/-}$mice failed to recapitulate the total NKT cell developmental arrest found in Sh2d1a $a^{-/-}$ mice (20) (Figure 1), we conclude that there must be yet another SLAMF receptor that is able to recruit SAP in the absence of Slamf1, Slamf5, and Slamf6. As we could not detect Slamf4 expression in DP thymocytes, we ruled out both Slamf2 and Slamf4 from the list of possible candidates. Since Slamf3 $3^{-/}$B6 mice were reported not to have a decrease in NKT cell number (58), we can also rule 

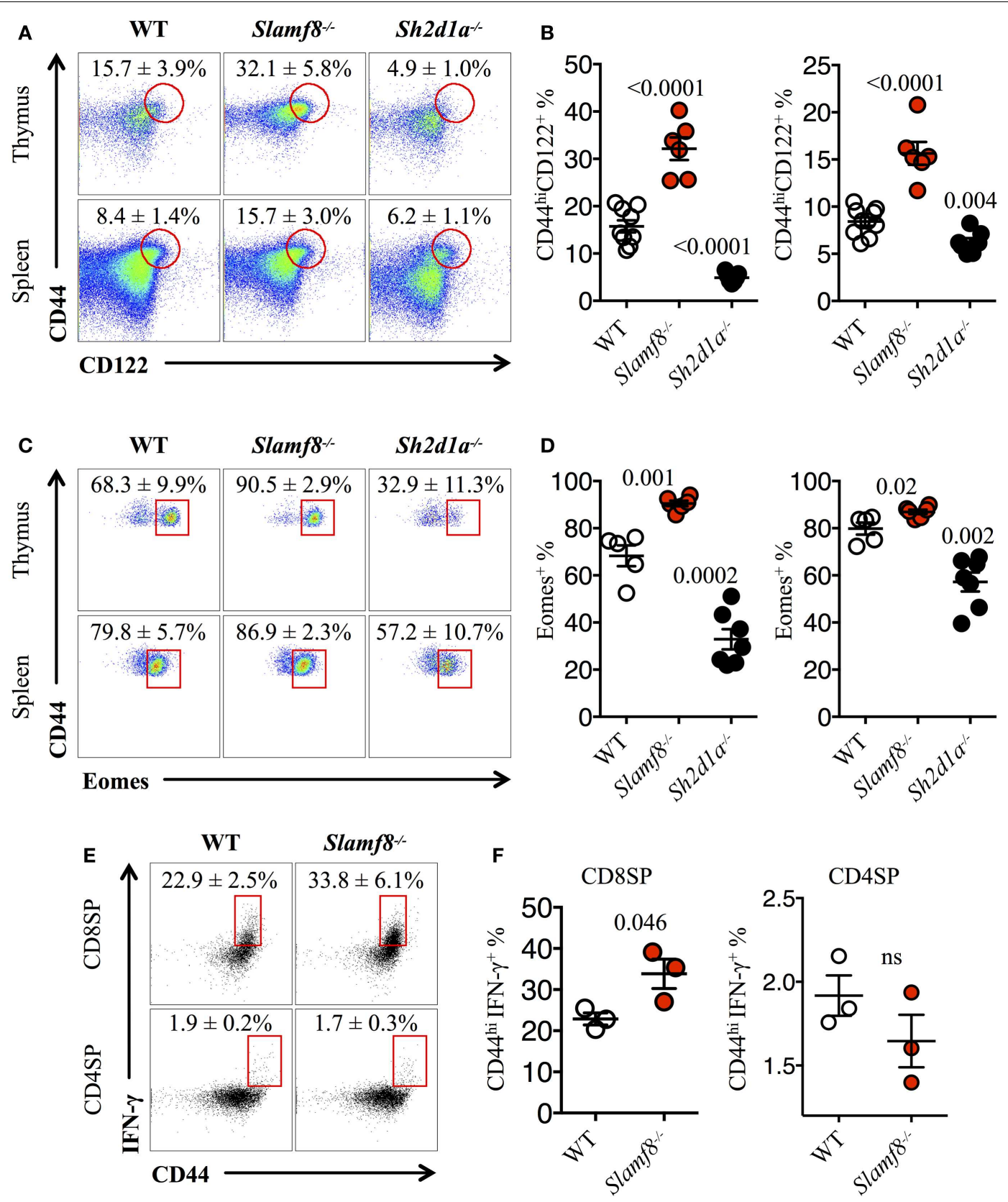

FIGURE 5 | Slamf8 ${ }^{--}$mice have an enlarged $\mathrm{CDB}^{+} \mathrm{T}$ cell compartment with innate-like features. (A) Representative FACS plots showing the expression of CD44 and CD122 on CD8SPT cells from thymus or spleen of WT, Slamf8 $8^{--}$or Sh2d1a $a^{-1}$ BALB/c mice. FACS plots are gated on live singlets lymphocytes TCR $\beta^{\text {hi }}$ CD8SP (thymus) or TCR $\beta^{+}$CD8SP (spleen). (B) Percentage of CD44hi $\mathrm{CD} 122^{+}$CD8SPT cells in thymus (left) or spleen (right) of WT, Slamf8 ${ }^{-1}$ or Sh2d1 $a^{-/}$BALB/c mice. (C) Intracellular staining for the transcription factor Eomesodermin (Eomes) in thymus or spleen of WT, Slamf8 $8^{--}$or Sh2d1 $a^{--}$BALB/c mice. FACS plots are gated on live singlets lymphocytes $C D 44^{\text {hi }} C D 122^{+}$TCR $\beta^{\text {hi }}$ CD8SPT cells. (D) Percentage of
Eomes ${ }^{+}$innate-like CD8 ${ }^{+} \mathrm{T}$ cells in thymus (left) or spleen (right) of WT, Slamf8- or Sh2d1 $a^{-/}$BALB/c mice. (E) Intracellular staining for IFN- $\gamma$ after ex vivo activation with PMA and ionomycin of WT or Slamf8-1- BALB/C thymocytes. (F) Percentage of CD44 $4^{\text {hi } I F N-~} \gamma^{+}$CD8SP (left) or CD44 $4^{\text {hi }} \mathrm{CD} 4 \mathrm{SP}$ (right) of WT or Slamf8- BALB/c thymocytes. Numbers inside plots show the mean percentage $\pm S D$ of the indicated population. Cumulative graphs show the results of four independent experiments, mean \pm SEM. The $p$ values were calculated by unpaired $t$-test between the WT group and the Slamf8 ${ }^{-1}$ or Sh $2 d 1 a^{-1-}$ group. A value of $p<0.05$ was considered significant; ns, non-significant. out this receptor. We then tested Slamf5 $5^{-/-}$and Slamf $^{-1-}$ B6 mice. Surprisingly, instead of a decrease in NKT and/or innate $\mathrm{CD}^{+} \mathrm{T}$ cells, we found a significant increase of both these cell populations in these mice (Figures $\mathbf{2}$ and $\mathbf{3}$ ), suggesting that these receptors act as negative regulators during innate $\mathrm{T}$ cell development. However, as it was shown for Slamf6 expression, in which this receptor was able to provide both positive and negative signals to NKT cell development in a SAP-dependent manner (53), 

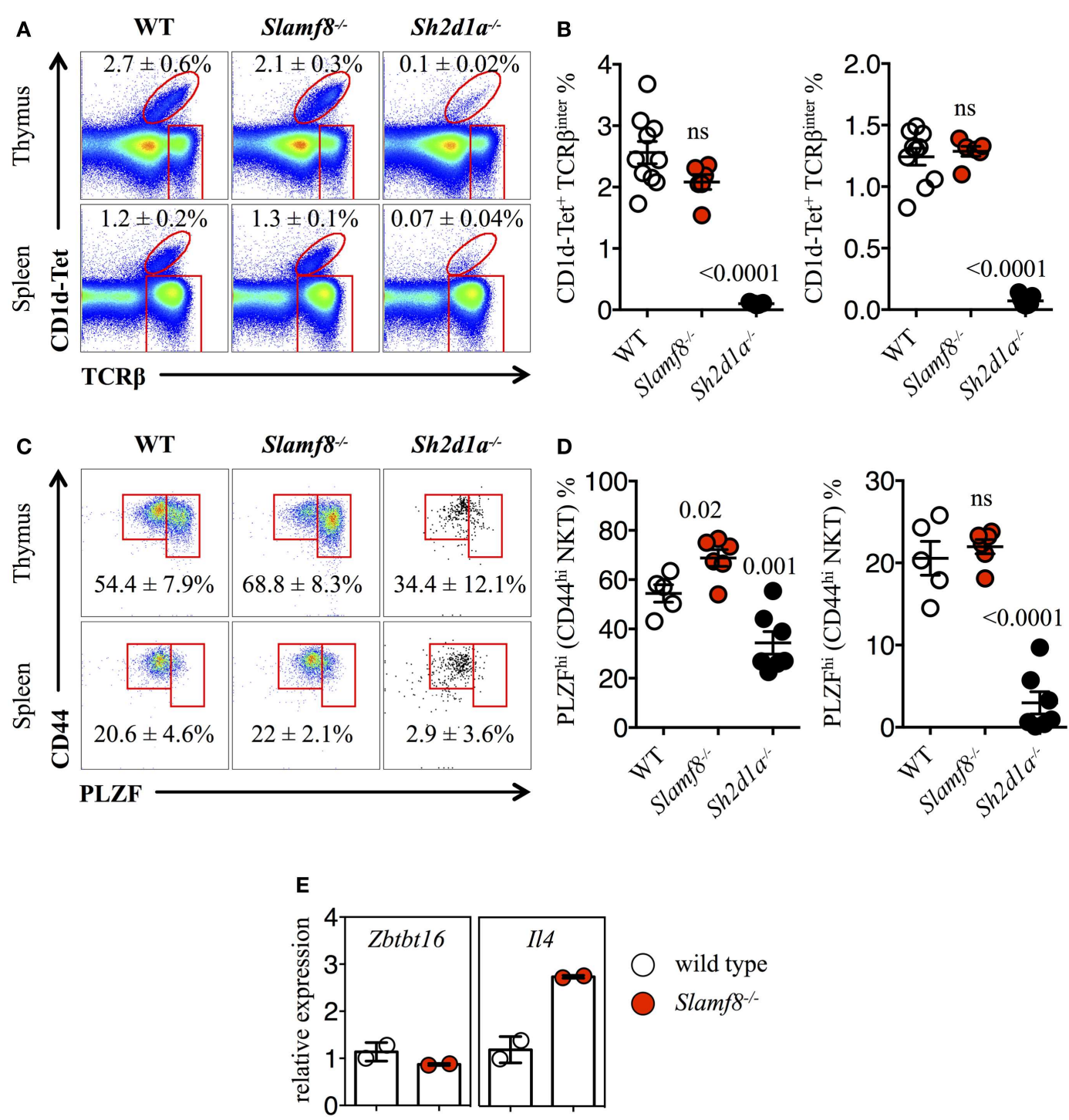

FIGURE 6 | Increased percentage of PLZFi NKT cells in Slamf8 ${ }^{-/-}$ mice. (A) Representative FACS plots showing PBS-57 CD1d-tetramer (CD1d-Tet) reactive NKT cells from thymus or spleen of WT, Slamf8 ${ }^{-1-}$ or Sh2d1a ${ }^{-/}$BALB/c mice. FACS plots are gated on live singlets lymphocytes. (B) Percentage of CD1d-Tet ${ }^{+} T C R \beta^{\text {inter }}$ cells in thymus (left) or $\mathrm{CD} 1 \mathrm{~d}-\mathrm{Tet}^{+}{ }^{\mathrm{TCR}} \beta^{+}$in spleen (right). (C) Intracellular staining for the transcription factor promyelocytic leukemia zinc finger (PLZF) in thymus

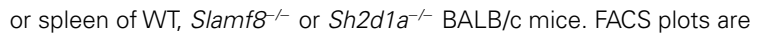
gated on live singlets CD1d-Tet ${ }^{+} T C R \beta^{\text {inter }}$ cells. (D) Percentage of PLZF ${ }^{\text {hi }}$ NKT cells in thymus (left) or spleen (right) of WT, Slamf8- or Sh2d1 $a^{-1}$ BALB/c mice. (E) The relative mRNA expression of Zbtb16 (encoding
PLZF) and IL-4 (encoding Interleukin-4) was determined in total thymocytes from WT or Slamf8-- BALB/c mice by real-time PCR. Results were normalized to the expression of the housekeeping gene $18 \mathrm{~S}$ rRNA and expressed relative to WT BALB/c levels (WT $=1$ ). Numbers inside plots show the mean percentage \pm SD of NKT cells $(\mathbf{A})$, or PLZF ${ }^{\text {hi }}$ NKT cells for (C). Red rectangles in (A) depict the lymphocyte gate in which innate $\mathrm{CD} 8^{+} \mathrm{T}$ cells were analyzed. Cumulative graphs show the results of three independent experiments, mean \pm SEM. The $p$ values were calculated by unpaired $t$-test between the WT group and the Slamf8- $8^{--}$or Sh $2 d 1 a^{-/}$group. A value of $p<0.05$ was considered significant; ns, non-significant. it is still possible that in the presence of other SLAMF receptors, Slamf5 and Slamf7 play opposite roles to the signals coming from Slamf1 and Slamf6. Further experiments will hopefully shed light on this rather intricate but important relationship.

Interestingly, the reduction of NKT cells in Slamf $[1+6]^{-/-}$ and Slamf $[1+5+6]^{-/-}$mice, or the complete absence of these cells in Sh $2 d_{1 a^{-/}}$B6 mice, did not seem to impair the generation of innate-like $\mathrm{CD}^{+} \mathrm{T}$ cells (Figure 1; Table 2). As these results contradicted published evidence showing that NKT cells support the expansion of innate CD8 ${ }^{+}$T cells via IL-4 production (10), and that SAP expression is required for thymic selection of innate-like $\mathrm{CD}^{+} \mathrm{T}$ cells in $I t k^{-/-}$mice (40), we sought to test if the absence of NKT cells in an otherwise normal SAP context would also affect innate $\mathrm{CD} 8^{+} \mathrm{T}$ cell development. Hence, we analyzed the presence of innate-like $\mathrm{CD} 8^{+} \mathrm{T}$ cells in $J \alpha 18^{-/-}$mice (Figures 1E,F). Similar to our previous observations in Sh2d1 $a^{-/-}$B6 mice, we did not 
detect a reduction of $\mathrm{CD} 44^{\mathrm{hi}} \mathrm{CD} 122^{+}$cells in this NKT-deficient strain (Figures 1E,F), suggesting that in the absence of NKT cells other cells can provide the factors needed to accomplish this task.

Since all murine SLAMF receptors that have one or more cytoplasmic ITSM, with the exception of Slamf2, Slamf8, and Slamf9, can theoretically recruit SAP and/or EAT-2A, a redundancy in their function during innate cell development can be expected. Supporting this idea, none of the single SLAMF-deficient mice generated on the B6 background have shown substantial alterations in their innate $\mathrm{T}$ cell compartments (Table 2). Remarkably, however, Slamf3 $3^{-1-}$ (22) and now Slamf8 ${ }^{-/-}$mice (this work), both on the BALB/c background, show massive expansions of innate-like $\mathrm{CD}^{+} \mathrm{T}$ cells in the thymus (Table 3), albeit to a far lesser extent than the $I t k^{-/-}$or $\mathrm{Rlk}^{-/-} \mathrm{Itk}^{-/-} \mathrm{B} 6$ mice. These results strongly suggest that the mouse background can somehow act as a pressure selector of innate $\mathrm{T}$ cell development.

The recent identification of a specialized NKT cell subset present in $\mathrm{BALB} / \mathrm{c}$ mice, but practically absent in $\mathrm{B} 6$ mice, capable of constantly producing IL-4 (termed NKT2), allowed Lee et al. to propose a model in which NKT2 cells are readily available in the thymus to secrete IL-4, resulting in intrinsically greater frequencies of innate $\mathrm{CD} 8^{+} \mathrm{T}$ cells (43) on this mouse background. Notably, these cells express the highest levels of PLZF among all mature NKT cells. Consequently, an involvement of NKT2 cells in supporting the expansion of innate-like $\mathrm{CD} 8^{+} \mathrm{T}$ cells in Slamf8 ${ }^{-1-}$ mice can be anticipated, as we find an enlarged PLZF ${ }^{\text {hi }}$ NKT population that correlates with a greater proportion of innate CD8 ${ }^{+}$ $\mathrm{T}$ cells in these mice (Figures $\mathbf{5}$ and $\mathbf{6}$ ). However, the underlying mechanism by which the absence of Slamf8 favors the expansion of PLZF ${ }^{\text {hi }}$ NKT cells remains undetermined. Since Slamf 8 mRNA is expressed by DC and fibroblasts in the thymus, but not DP thymocytes (Table 1), we speculate that these cells may be providing some sort of signal to developing NKT and/or innate $\mathrm{CD} 8^{+} \mathrm{T}$ cells which is affected by the absence of Slamf8. In this context, IL-15 transpresentation has been shown to mediate survival of mature thymic NKT and innate CD8 $\alpha \alpha^{+}$intestinal intraepithelial T cells (67-70). Thus, Slamf8 may be regulating the production and/or transpresentation of this cytokine.

By investigating the impact of two previously uncharacterized SLAMF receptors (Slamf7 and Slamf8) as well as the combined impact of multiple SLAMF receptor deletions (Slamf $[1+6]^{-/-}$ and Slamf $[1+5+6]^{-1-}$ mice), we are able to present new evidence that shall complement previous knowledge concerning the individual contributions of SLAMF receptors to NKT and innate $\mathrm{CD}^{+} \mathrm{T}$ cell biology. Importantly, the outcomes of our studies show the existence of positive and negative signals derived from different SLAMF receptors (Tables 2 and $\mathbf{3}$ ), which together orchestrate innate $\mathrm{T}$ cell development. The cellular and molecular mechanisms behind these observations certainly deserve more attention in the future, since these pathways could potentially be targeted in the aid of expanding innate $\mathrm{T}$ cell populations in situations where SAP is absent, such as in patients with XLP.

\section{ACKNOWLEDGMENTS}

Jaime De Calisto and Ninghai Wang performed most of the experiments and analyzed the data. We thank Guoxing Wang, Cynthia Detre, Peter Halibozek, and Michael O'Keeffe for help with some of the experiments, and Gongxian Liao, Michael O'Keeffe and Boaz Van Driel for thoughtful discussions and proofreading the manuscript. This work was supported by the National Institutes of Health (P01 AI-076210 and R01 AI-15066 to Cox Terhorst).

\section{SUPPLEMENTARY MATERIAL}

The Supplementary Material for this article can be found online at http://www.frontiersin.org/Journal/10.3389/fimmu.2014.00186/ abstract

Figure S1 | General gating strategy for the identification of innate (B6) T cells, and SLAMF receptor expression by FACS. (A) Genomic organization of the nine SLAMF genes, and the two adaptors Sh2d1b1 and Sh2d1b2 (encoding EAT-2A and ERT, respectively) on the murine chromosome $1 \mathrm{H} 3$. Blue filled boxes with a red frame represent SLAMF receptors containing one or more ITSM. Black empty boxes represent SLAMF receptors that lack ITSM. Red and orange boxes represent the Sh2d1b1 and Sh2d1b2 genes, respectively. This diagram also illustrates the Slamf $[1+6]^{-\alpha}$ and Slamf $[1+5+6]^{-1}$ deletions used in this manuscript. (B) FACS plots showing the main gating strategy used on the analysis of NKT and innate $\mathrm{CD} 8^{+} \mathrm{T}$ cells in $\mathrm{B} 6$ mice. Upper row from left to right: live cells (DAPI negative), singlets, lymphocytes, and total thymocytes depicting the NKT (CD1d-Tet ${ }^{+} T C R \beta^{\text {inter }}$ ), the TCR $\beta^{\text {hi }}$ mature, and TCR $\beta^{\text {low }}$ immature thymocytes gates. Middle row from left to right: $\mathrm{CD} 4^{+} \mathrm{CD} 8^{+} \mathrm{DP}$ TCR $\beta^{\text {low }}$ immature thymocytes, mature $\left(C D 44^{+} N K 1.1^{+}\right)$NKT cells, TCR $\beta^{\text {hi }}$ mature T cells [depicting CD8 and CD4 single positive (SP) mature thymocytes], and CD8SPT cells depicting the innate $\mathrm{CD} 8^{+} \mathrm{T}$ cell population in the thymus. Bottom row from left to right, mature $\left(\mathrm{CD} 44^{+} \mathrm{NK} 1.1^{+}\right) \mathrm{NKT}$ cells, TCR $\beta^{+}$T cells [depicting CD8 and CD4 single positive (SP) splenocytes], and CD8SPT cells depicting the innate $\mathrm{CD}^{+} \mathrm{T}$ cell population in the spleen. (C) Representative FACS staining of innate $\mathrm{CD} 8^{+} \mathrm{T}$ cells $\left(\mathrm{CD} 44^{\text {hi }} \mathrm{CD} 122^{+} \mathrm{TCR} \beta^{+}\right)$showing the corresponding fluorescence minus one (FMO) negative control for the CD122 gate in thymus and spleen from WT cells. (D) Representative FACS histograms showing the expression of Slamf1, Slamf2, Slamf3, Slamf4, Slamf5, and Slamf6 on the surface of $\mathrm{CD}^{+}{ }^{+} \mathrm{CD} 8^{+}$DPTCR ${ }^{\text {low }}$ thymocytes (upper row, green), CD1d-tetramer (CD1d-Tet) reactive CD44 hKi ${ }^{\text {hi }}$ cells (red, NKT), or on $\mathrm{CD} 44^{\text {hi }} \mathrm{CD} 122^{+} \mathrm{TCR} \beta^{\text {hi }}$ (thymus, middle row), or TCR $\beta^{+}$(spleen, bottom row) CD8SPT cells (purple, innate-like CD8) of 10-week-old B6 mice. Gray histograms represent the FMO negative control for the Slamf staining.

Figure S2 | General gating strategy for the identification of innate (BALB/c) $T$ cells by FACS. (A) FACS plots showing the main gating strategy used on the analysis of NKT and innate $C D 8^{+} T$ cells in BALB/c mice. Upper row from left to right: live cells (DAPI negative), singlets, lymphocytes, and total thymocytes depicting the NKT (CD1d-Tet $\left.{ }^{+} T C R \beta^{\text {inter }}\right)$, and the TCR $\beta^{\text {hi }}$ mature lymphocyte gates. Bottom row from left to right: total live thymocytes depicting the CD8 single positive (SP), the CD4SP, and the $\mathrm{CD} 4^{+} \mathrm{CD} 8^{+} \mathrm{DPTCR} \beta^{\text {low }}$ immature thymocytes. (B) Representative FACS staining of innate $\mathrm{CD} 8^{+} \mathrm{T}$ cells $\left(\mathrm{CD} 44^{\mathrm{hi}} \mathrm{CD} 122^{+} \mathrm{TCR} \beta^{+}\right)$showing the corresponding FMO (fluorescence minus one) negative control for the CD122 gate (left), or Eomesodermin (Eomes, right) in thymus and spleen from WT cells.

\section{REFERENCES}

1. Hogquist KA. Signal strength in thymic selection and lineage commitment. Curr Opin Immunol (2001) 13:225-31. doi:10.1016/S0952-7915(00)00208-9

2. Starr TK, Jameson SC, Hogquist KA. Positive and negative selection of T cells. Annu Rev Immunol (2003) 21:139-76. doi:10.1146/annurev.immunol.21. 120601.141107

3. Berg LJ. Signaling pathways that regulate T cell development and differentiation. J Immunol (2012) 189:5487-8. doi:10.4049/jimmunol.1290076

4. Germain RN. T-cell development and the CD4-CD8 lineage decision. Nat Rev Immunol (2002) 2:309-22. doi:10.1038/nri798

5. Palmer E. Negative selection - clearing out the bad apples from the T-cell repertoire. Nat Rev Immunol (2003) 3:383-91. doi:10.1038/nri1085

6. Singer A, Adoro S, Park JH. Lineage fate and intense debate: myths, models and mechanisms of CD4- versus CD8-lineage choice. Nat Rev Immunol (2008) 8:788-801. doi:10.1038/nri2416 
7. Klein L, Hinterberger M, Wirnsberger G, Kyewski B. Antigen presentation in the thymus for positive selection and central tolerance induction. Nat Rev Immunol (2009) 9:833-44. doi:10.1038/nri2669

8. Urdahl KB, Sun JC, Bevan MJ. Positive selection of MHC class Ib-restricted CD8(+) T cells on hematopoietic cells. Nat Immunol (2002) 3:772-9. doi:10. 1038/ni814

9. Bendelac A, Savage PB, Teyton L. The biology of NKT cells. Annu Rev Immunol (2007) 25:297-336. doi:10.1146/annurev.immunol.25.022106.141711

10. Lee YJ, Jameson SC, Hogquist KA. Alternative memory in the CD8 T cell lineage. Trends Immunol (2011) 32:50-6. doi:10.1016/j.it.2010.12.004

11. Rodgers JR, Cook RG. MHC class Ib molecules bridge innate and acquired immunity. Nat Rev Immunol (2005) 5:459-71. doi:10.1038/nri1635

12. Godfrey DI, Pellicci DG, Patel O, Kjer-Nielsen L, Mccluskey J, Rossjohn J. Antigen recognition by CD1d-restricted NKT T cell receptors. Semin Immunol (2010) 22:61-7. doi:10.1016/j.smim.2009.10.004

13. Hofstetter AR, Sullivan LC, Lukacher AE, Brooks AG. Diverse roles of nondiverse molecules: MHC class Ib molecules in host defense and control of autoimmunity. Curr Opin Immunol (2011) 23:104-10. doi:10.1016/j.coi.2010. 09.009

14. Mallevaey T, Clarke AJ, Scott-Browne JP, Young MH, Roisman LC, Pellicci DG, et al. A molecular basis for NKT cell recognition of CD1d-self-antigen. Immunity (2011) 34:315-26. doi:10.1016/j.immuni.2011.01.013

15. Berg LJ. Signalling through TEC kinases regulates conventional versus innate CD8(+) T-cell development. Nat Rev Immunol (2007) 7:479-85. doi:10.1038/ nri2091

16. Borowski C, Bendelac A. Signaling for NKT cell development: the SAP-FynT connection. J Exp Med (2005) 201:833-6. doi:10.1084/jem.20050339

17. Chung B, Aoukaty A, Dutz J, Terhorst C, Tan R. Signaling lymphocytic activation molecule-associated protein controls NKT cell functions. JImmunol (2005) 174:3153-7.

18. Nichols KE, Hom J, Gong SY, Ganguly A, Ma CS, Cannons JL, et al. Regulation of NKT cell development by SAP, the protein defective in XLP. Nat Med (2005) 11:340-5. doi:10.1038/nm1189

19. Pasquier B, Yin L, Fondaneche MC, Relouzat F, Bloch-Queyrat C, Lambert N, et al. Defective NKT cell development in mice and humans lacking the adapter SAP, the X-linked lymphoproliferative syndrome gene product. JExp Med (2005) 201:695-701. doi:10.1084/jem.20042432

20. Griewank K, Borowski C, Rietdijk S, Wang N, Julien A, Wei DG, et al. Homotypic interactions mediated by Slamf1 and Slamf6 receptors control NKT cell lineage development. Immunity (2007) 27:751-62. doi:10.1016/j.immuni.2007.08.020

21. Detre C, Keszei M, Garrido-Mesa N, Kis-Toth K, Castro W, Agyemang AF, et al. SAP expression in invariant NKT cells is required for cognate help to support B-cell responses. Blood (2012) 120:122-9. doi:10.1182/blood-2011-11-395913

22. Sintes J, Cuenca M, Romero X, Bastos R, Terhorst C, Angulo A, et al. Cutting edge: Ly9 (CD229), a SLAM family receptor, negatively regulates the development of thymic innate memory-like CD8+ T and invariant NKT cells. J Immunol (2013) 190:21-6. doi:10.4049/jimmunol.1202435

23. Calpe S, Wang N, Romero X, Berger SB, Lanyi A, Engel P, et al. The SLAM and SAP gene families control innate and adaptive immune responses. Adv Immunol (2008) 97:177-250. doi:10.1016/S0065-2776(08)00004-7

24. Veillette A. SLAM-family receptors: immune regulators with or without SAPfamily adaptors. Cold Spring Harb Perspect Biol (2010) 2:a002469. doi:10.1101/ cshperspect.a002469

25. Cannons JL, Tangye SG, Schwartzberg PL. SLAM family receptors and SAP adaptors in immunity. Annu Rev Immunol (2011) 29:665-705. doi:10.1146/annurevimmunol-030409-101302

26. Chan B, Lanyi A, Song HK, Griesbach J, Simarro-Grande M, Poy F, et al. SAP couples Fyn to SLAM immune receptors. Nat Cell Biol (2003) 5:155-60. doi:10.1038/ncb920

27. Latour S, Roncagalli R, Chen R, Bakinowski M, Shi X, Schwartzberg PL, et al. Binding of SAP SH2 domain to FynT SH3 domain reveals a novel mechanism of receptor signalling in immune regulation. Nat Cell Biol (2003) 5:149-54. doi: $10.1038 /$ ncb919

28. Sayos J, Wu C, Morra M, Wang N, Zhang X, Allen D, et al. The Xlinked lymphoproliferative-disease gene product SAP regulates signals induced through the co-receptor SLAM. Nature (1998) 395:462-9. doi:10.1038/26683

29. Poy F, Yaffe MB, Sayos J, Saxena K, Morra M, Sumegi J, et al. Crystal structures of the XLP protein SAP reveal a class of SH2 domains with extended, phosphotyrosine-independent sequence recognition. Mol Cell (1999) 4:555-61. doi:10.1016/S1097-2765(00)80206-3

30. Li C, Iosef C, Jia CY, Han VK, Li SS. Dual functional roles for the X-linked lymphoproliferative syndrome gene product SAP/SH2D1A in signaling through the signaling lymphocyte activation molecule (SLAM) family of immune receptors. J Biol Chem (2003) 278:3852-9. doi:10.1074/jbc.M206649200

31. Eberl G, Lowin-Kropf B, Macdonald HR. Cutting edge: NKT cell development is selectively impaired in Fyn-deficient mice. J Immunol (1999) 163:4091-4.

32. Gadue P, Morton N, Stein PL. The Src family tyrosine kinase Fyn regulates natural killer T cell development. J Exp Med (1999) 190:1189-96. doi:10.1084/jem. 190.8.1189

33. Zhang X, Sun S, Hwang I, Tough DF, Sprent J. Potent and selective stimulation of memory-phenotype CD8+ T cells in vivo by IL-15. Immunity (1998) 8:591-9. doi:10.1016/S1074-7613(00)80564-6

34. Dubois S, Waldmann TA, Muller JR. ITK and IL-15 support two distinct subsets of CD8+ T cells. Proc Natl Acad Sci U S A (2006) 103:12075-80. doi:10.1073/pnas.0605212103

35. Castillo EF, Schluns KS. Regulating the immune system via IL-15 transpresentation. Cytokine (2012) 59:479-90. doi:10.1016/j.cyto.2012.06.017

36. Freeman BE, Hammarlund E, Raue HP, Slifka MK. Regulation of innate CD8+ T-cell activation mediated by cytokines. Proc Natl Acad Sci U S A (2012) 109:9971-6. doi:10.1073/pnas.1203543109

37. Schaeffer EM, Broussard C, Debnath J, Anderson S, Mcvicar DW, Schwartzberg PL. Tec family kinases modulate thresholds for thymocyte development and selection. J Exp Med (2000) 192:987-1000. doi:10.1084/jem.192.7.987

38. Atherly LO, Lucas JA, Felices M, Yin CC, Reiner SL, Berg LJ. The Tec family tyrosine kinases Itk and Rlk regulate the development of conventional CD8+ T cells. Immunity (2006) 25:79-91. doi:10.1016/j.immuni.2006.05.012

39. Broussard C, Fleischacker C, Horai R, Chetana M, Venegas AM, Sharp LL, et al. Altered development of CD8+ T cell lineages in mice deficient for the Tec kinases Itk and Rlk. Immunity (2006) 25:93-104. doi:10.1016/j.immuni.2006.10.009

40. Horai R, Mueller KL, Handon RA, Cannons JL, Anderson SM, Kirby MR, et al. Requirements for selection of conventional and innate $\mathrm{T}$ lymphocyte lineages. Immunity (2007) 27:775-85. doi:10.1016/j.immuni.2007.09.012

41. Verykokakis M, Boos MD, Bendelac A, Kee BL. SAP protein-dependent natural killer T-like cells regulate the development of CD8(+) T cells with innate lymphocyte characteristics. Immunity (2010) 33:203-15. doi:10.1016/j.immuni. 2010.07.013

42. Weinreich MA, Odumade OA, Jameson SC, Hogquist KA. T cells expressing the transcription factor PLZF regulate the development of memory-like CD8+ T cells. Nat Immunol (2010) 11:709-16. doi:10.1038/ni.1898

43. Lee YJ, Holzapfel KL, Zhu J, Jameson SC, Hogquist KA. Steady-state production of IL-4 modulates immunity in mouse strains and is determined by lineage diversity of iNKT cells. Nat Immunol (2013) 14:1146-54. doi:10.1038/ ni. 2731

44. Pearce EL, Mullen AC, Martins GA, Krawczyk CM, Hutchins AS, Zediak VP, et al. Control of effector CD8+ T cell function by the transcription factor Eomesodermin. Science (2003) 302:1041-3. doi:10.1126/science.1090148

45. Takemoto N, Intlekofer AM, Northrup JT, Wherry EJ, Reiner SL. Cutting Edge: IL-12 inversely regulates T-bet and eomesodermin expression during pathogeninduced CD8+ T cell differentiation. J Immunol (2006) 177:7515-9.

46. Kaech SM, Cui W. Transcriptional control of effector and memory CD8+ T cell differentiation. Nat Rev Immunol (2012) 12:749-61. doi:10.1038/nri3307

47. Wu C, Nguyen KB, Pien GC, Wang N, Gullo C, Howie D, et al. SAP controls T cell responses to virus and terminal differentiation of TH2 cells. Nat Immunol (2001) 2:410-4. doi:10.1038/ni0901-823

48. Wang G, Abadia-Molina AC, Berger SB, Romero X, O'Keeffe MS, RojasBarros DI, et al. Cutting edge: Slamf8 is a negative regulator of Nox2 activity in macrophages. J Immunol (2012) 188:5829-32. doi:10.4049/jimmunol. 1102620

49. Tung JW, Parks DR, Moore WA, Herzenberg LA, Herzenberg LA. New approaches to fluorescence compensation and visualization of FACS data. Clin Immunol (2004) 110:277-83. doi:10.1016/j.clim.2003.11.016

50. Herzenberg LA, Tung J, Moore WA, Herzenberg LA, Parks DR. Interpreting flow cytometry data: a guide for the perplexed. Nat Immunol (2006) 7:681-5. doi:10.1038/ni0706-681

51. Barker BR. Measuring T cell function in innate immune models. Methods Mol Biol (2013) 1031:77-90. doi:10.1007/978-1-62703-481-4_10 
52. Heng TSP, Painter MW, The Immunological Genome Project Consortium, Elpek K, Lukacs-Kornek V, Mauermann N, et al. The Immunological Genome Project: networks of gene expression in immune cells. Nat Immunol (2008) 9:1091-4. doi:10.1038/ni1008-1091

53. Kageyama R, Cannons JL, Zhao F, Yusuf I, Lao C, Locci M, et al. The receptor Ly108 functions as a SAP adaptor-dependent on-off switch for T cell help to B cells and NKT cell development. Immunity (2012) 36:986-1002. doi:10.1016/j.immuni.2012.05.016

54. Nunez-Cruz S, Yeo WC, Rothman J, Ojha P, Bassiri H, Juntilla M, et al. Differential requirement for the SAP-Fyn interaction during NK T cell development and function. J Immunol (2008) 181:2311-20.

55. Bediako Y, Bian Y, Zhang H, Cho H, Stein PL, Wang CR. SAP is required for the development of innate phenotype in H2-M3 - restricted Cd8(+) T cells. J Immunol (2012) 189:4787-96. doi:10.4049/jimmunol.1200579

56. Jordan MA, Fletcher JM, Pellicci D, Baxter AG. Slamf1, the NKT cell control gene Nkt1. J Immunol (2007) 178:1618-27.

57. Jordan MA, Fletcher JM, Jose R, Chowdhury S, Gerlach N, Allison J, et al. Role of SLAM in NKT cell development revealed by transgenic complementation in NOD mice. J Immunol (2011) 186:3953-65. doi:10.4049/jimmunol.1003305

58. Graham DB, Bell MP, Mccausland MM, Huntoon CJ, Van Deursen J, Faubion WA, et al. Ly9 (CD229)-deficient mice exhibit T cell defects yet do not share several phenotypic characteristics associated with SLAM- and SAP-deficient mice. J Immunol (2006) 176:291-300.

59. Cui J, Shin T, Kawano T, Sato H, Kondo E, Toura I, et al. Requirement for Valpha14 NKT cells in IL-12-mediated rejection of tumors. Science (1997) 278:1623-6. doi:10.1126/science.278.5343.1623

60. Nayar R, Enos M, Prince A, Shin H, Hemmers S, Jiang JK, et al. TCR signaling via Tec kinase ITK and interferon regulatory factor 4 (IRF4) regulates CD8+ T-cell differentiation. Proc Natl Acad Sci U S A (2012) 109:E2794-802. doi:10.1073/pnas.1205742109

61. Min HS, Lee YJ, Jeon YK, Kim EJ, Kang BH, Jung KC, et al. MHC class IIrestricted interaction between thymocytes plays an essential role in the production of innate CD8+ T cells. J Immunol (2011) 186:5749-57. doi:10.4049/ jimmunol.1002825

62. Kovalovsky D, Uche OU, Eladad S, Hobbs RM, Yi W, Alonzo E, et al. The BTBzinc finger transcriptional regulator PLZF controls the development of invariant natural killer T cell effector functions. Nat Immunol (2008) 9:1055-64. doi:10.1038/ni.1641

63. Savage AK, Constantinides MG, Han J, Picard D, Martin E, Li B, et al. The transcription factor PLZF directs the effector program of the NKT cell lineage. Immunity (2008) 29:391-403. doi:10.1016/j.immuni.2008.07.011
64. Gleimer M, Von Boehmer H, Kreslavsky T. PLZF controls the expression of a limited number of genes essential for NKT cell function. Front Immunol (2012) 3:374. doi:10.3389/fimmu.2012.00374

65. Constantinides MG, Bendelac A. Transcriptional regulation of the NKT cell lineage. Curr Opin Immunol (2013) 25:161-7. doi:10.1016/j.coi.2013.01.003

66. Surh CD, Sprent J. T-cell apoptosis detected in situ during positive and negative selection in the thymus. Nature (1994) 372:100-3. doi:10.1038/ 372100a0

67. Schluns KS, Nowak EC, Cabrera-Hernandez A, Puddington L, Lefrancois L, Aguila HL. Distinct cell types control lymphoid subset development by means of IL-15 and IL-15 receptor alpha expression. Proc Natl Acad Sci U S A (2004) 101:5616-21. doi:10.1073/pnas.0307442101

68. Castillo EF, Stonier SW, Frasca L, Schluns KS. Dendritic cells support the in vivo development and maintenance of NK cells via IL-15 trans-presentation. J Immunol (2009) 183:4948-56. doi:10.4049/jimmunol.0900719

69. Chang CL, Lai YG, Hou MS, Huang PL, Liao NS. IL-15Ralpha of radiationresistant cells is necessary and sufficient for thymic invariant NKT cell survival and functional maturation. J Immunol (2011) 187:1235-42. doi:10.4049/ jimmunol.1100270

70. Gordy LE, Bezbradica JS, Flyak AI, Spencer CT, Dunkle A, Sun J, et al. IL-15 regulates homeostasis and terminal maturation of NKT cells. J Immunol (2011) 187:6335-45. doi:10.4049/jimmunol.1003965

Conflict of Interest Statement: The authors declare that the research was conducted in the absence of any commercial or financial relationships that could be construed as a potential conflict of interest.

Received: 15 February 2014; accepted: 08 April 2014; published online: 23 April 2014. Citation: De Calisto J, Wang N, Wang G, Yigit B, Engel P and Terhorst C (2014) $S A P$-dependent and-independent regulation of innate $T$ cell development involving SLAMF receptors. Front. Immunol. 5:186. doi: 10.3389/fimmu.2014.00186

This article was submitted to T Cell Biology, a section of the journal Frontiers in Immunology.

Copyright (c) 2014 De Calisto, Wang, Wang, Yigit, Engel and Terhorst. This is an openaccess article distributed under the terms of the Creative Commons Attribution License (CC BY). The use, distribution or reproduction in other forums is permitted, provided the original author(s) or licensor are credited and that the original publication in this journal is cited, in accordance with accepted academic practice. No use, distribution or reproduction is permitted which does not comply with these terms. 